
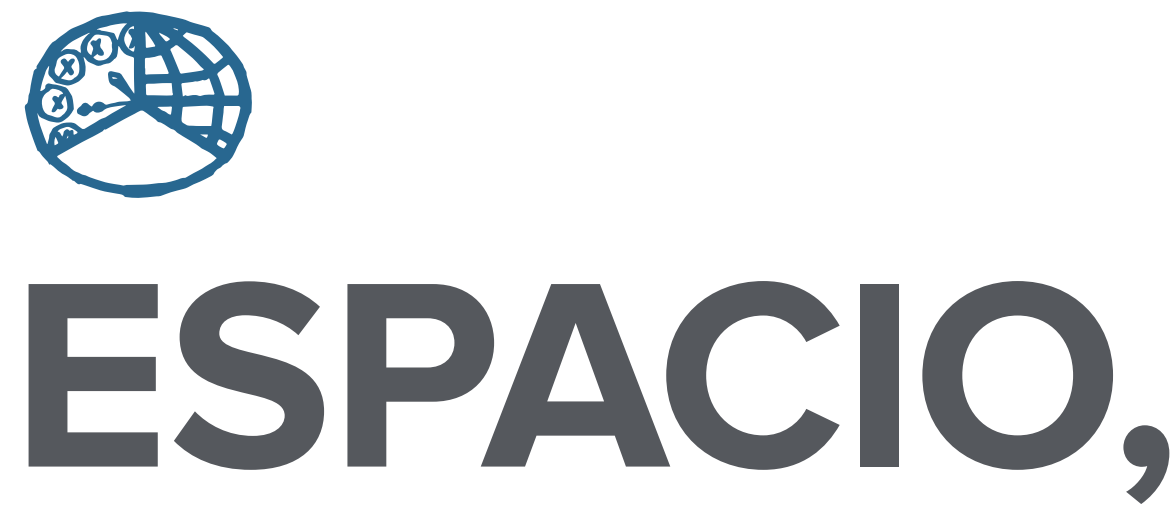

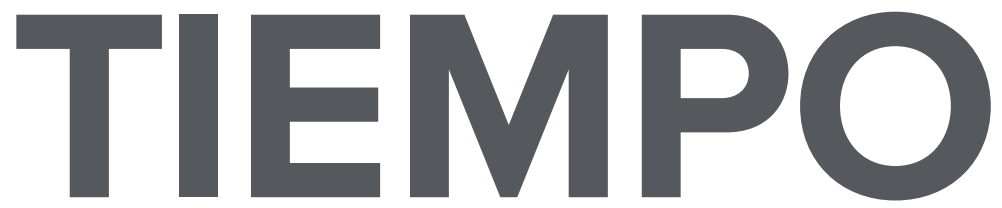

AÑO 2017 NUEVA ÉPOCA ISSN $1130-4715$

E-ISSN 2340-1478
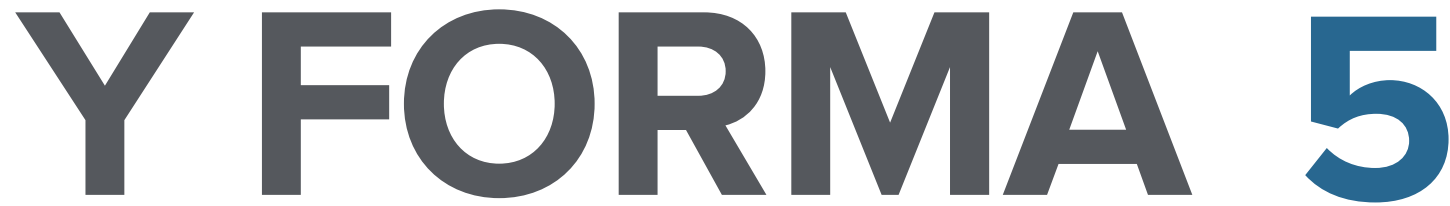

SERIE VII HISTORIA DEL ARTE

REVISTA DE LA FACULTAD DE GEOGRAFÍA E HISTORIA 


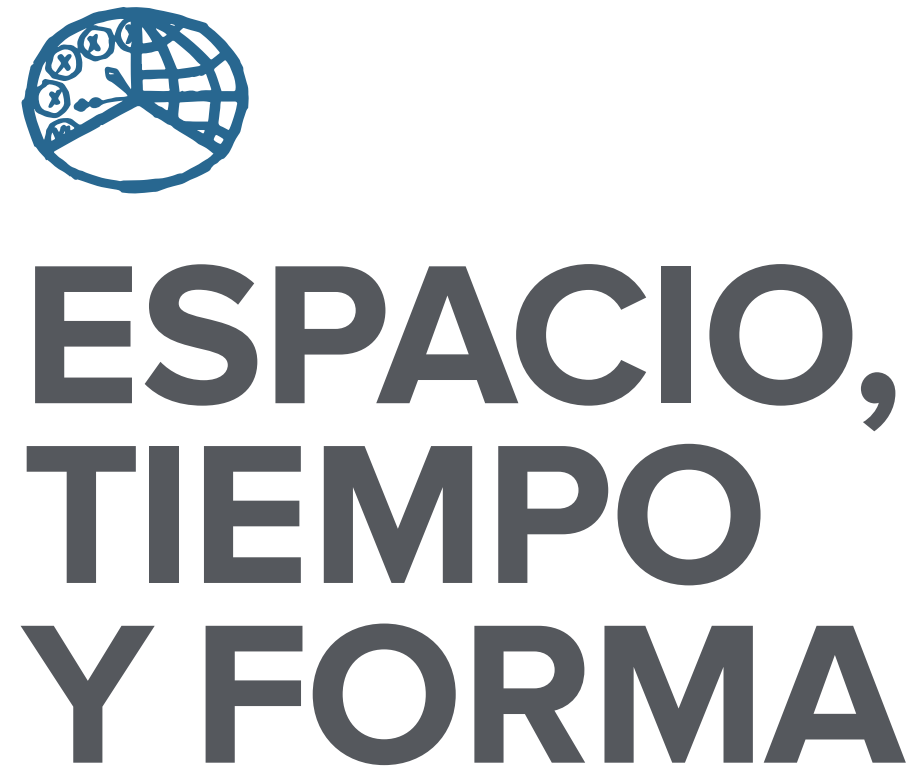

AÑO 2017

NUEVA ÉPOCA

ISSN $1130-4715$

E-ISSN 2340-1478

SERIE VII HISTORIA DEL ARTE

REVISTA DE LA FACULTAD DE GEOGRAFÍA E HISTORIA

DOI: http://dx.doi.org/10.5944/etfvii.5.2017

\section{UกED}

UNIVERSIDAD NACIONAL DE EDUCACIÓN A DISTANCIA 
La revista Espacio, Tiempo y Forma (siglas recomendadas: ETF), de la Facultad de Geografía e Historia de la UNED, que inició su publicación el año 1988, está organizada de la siguiente forma:

$$
\begin{aligned}
& \text { SERIE I - Prehistoria y Arqueología } \\
& \text { SERIE II - Historia Antigua } \\
& \text { SERIE III - Historia Medieval } \\
& \text { SERIE IV - Historia Moderna } \\
& \text { SERIE V - Historia Contemporánea } \\
& \text { SERIE VI - Geografía } \\
& \text { SERIE VII - Historia del Arte }
\end{aligned}
$$

Excepcionalmente, algunos volúmenes del año 1988 atienden a la siguiente numeración:

$$
\begin{aligned}
& \mathrm{N} .^{\circ} 1 \text { - Historia Contemporánea } \\
& \mathrm{N}^{\circ} 2 \text { - Historia del Arte } \\
& \mathrm{N} .^{\circ} 3 \text { - Geografía } \\
& \mathrm{N} .^{\circ} 4 \text { - Historia Moderna }
\end{aligned}
$$

ETF no se solidariza necesariamente con las opiniones expresadas por los autores.

Espacio, Tiempo y Forma, Serie vII está registrada e indexada, entre otros, por los siguientes Repertorios Bibliográficos y Bases de Datos: DICE, ISOC (CINDOC), RESH, IN-RECH, Dialnet, e-sPacio, UNED, CIRC, MIAR, FRANCIS, PIO, ULRICH'S, SUDOC, 2DB, ERIH (ESF).

UNIVERSIDAD NACIONAL DE EDUCACIÓN A DISTANCIA

Madrid, 2017

SERIE VII · HISTORIA DEL ARTE (NUEVA ÉPOCA) N. ${ }^{\circ}$ 5, 2017

ISSN $1130-4715 \cdot E-I S S N ~ 2340-1478$

DEPÓSITO LEGAL

M-21.037-1988

URL

ETF VII · HISTORIA DEL ARTE · http://revistas.uned.es/index.php/ETFVII

DISEÑO Y COMPOSICIÓN

Carmen Chincoa Gallardo · http://www.laurisilva.net/cch

Impreso en España · Printed in Spain 


\section{DOSSIER}

TREASURES OF THE SEA: ART BEFORE CRAFT?

Edited by Avinoam Shalem

TESOROS DEL MAR: ¿EL ARTE ANTES DE LA DESTREZA?

Editado por Avinoam Shalem 


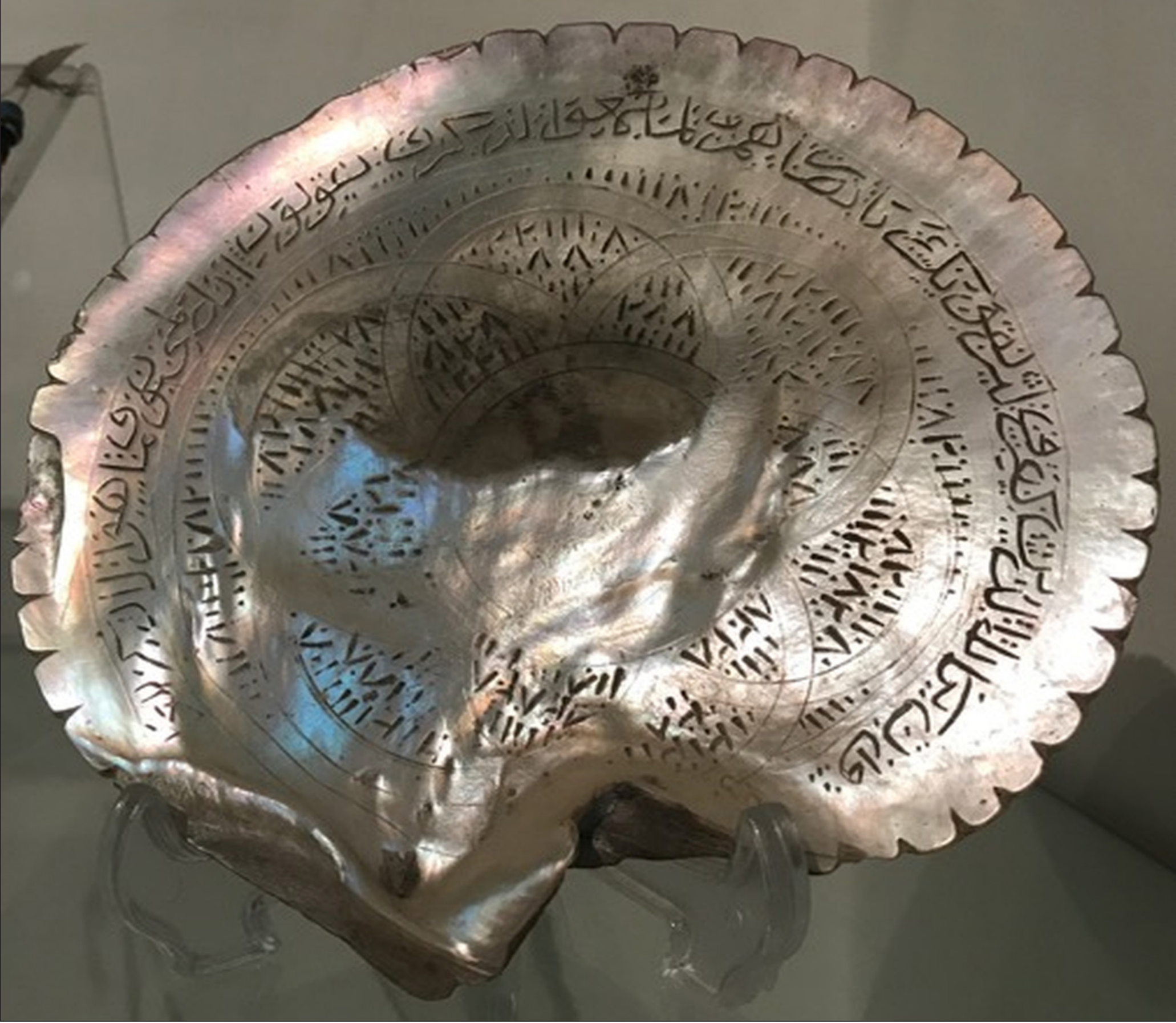

MOTHER-OF-PEARL INCISED WITH VERSES 51 AND 52 OF SURAT AL-QALAM ('THE PEN') AND WITH MAGICAL NUMBERS. NATIONAL MUSEUM OF HISTORY OF AZERBAIIAN, BAKU. Photo: Avinoam Shalem. 


\title{
A TALE OF TWO IVORIES: ELEPHANT AND WALRUS
}

\section{UNA HISTORIA DE DOS MARFILES: EL ELEFANTE Y LA MORSA ${ }^{1}$}

\author{
Matthew Elliott Gillman² \\ Recibido: 17/02/2017 - Aceptado: 18/4/2017 \\ DOI: http://dx.doi.org/10.5944/etfvii.2017.18314
}

\begin{abstract}
I propose that elephant and walrus ivory were imperfect substitutes in the medieval economy, appreciated and used as distinct substances. This argument draws upon two ongoing debates, though seemingly unrelated -one about the colonization of Greenland, one about a material known in Arabic as khutū. By reading different bodies of research against each other, I propose new avenues for research in the study of medieval art and trade networks. This uses a combination of historical, philological, artifactual, and material-based approaches. Rather than offering solutions, this essay seeks to open paths for research by specialists in various disciplines.
\end{abstract}

\section{Keywords}

Economics trade; Ivory - trade; Norse Atlantic; Odobenus rosmarus; Volga River; khutu.

\section{Resumen}

En este trabajo propongo que el marfil de elefante y de morsa fueron sustitutos imperfectos en la economía medieval, tratándose de materiales bien diferenciados, ambos utilizados y apreciados. Este argumento se basa en dos debates continuados, aunque aparentemente desvinculado -uno acerca de la colonización de Groenlandia, el otro acerca de un material conocido en lengua árabe como khutù. A través de la lectura de diferentes textos de investigación contrarios entre sí, propongo nuevas vías de investigación en el estudio de las redes del arte medieval y su comercio. Esto supone la utilización de una combinación de enfoques histórico, filológico, arqueológico y basado en la cultura material. Más que ofrecer soluciones, este

1. Author's Note: An excerpted version of this paper was presented as part of the Cambridge-Columbia Symposium in the History of Art on 13 February 2017, in New York, and 3 March 2017, at King's College, where it benefitted from collegial discussion. Thanks are due to Avinoam Shalem and especially two anonymous reviewers from the journal for suggestions which greatly clarified the essay in its longer form; any errors remain, of course, my own.

2. Matthew Elliott Gillman, Ph.D. candidate, Department of Art History and Archaeology, Columbia University in the City of New York. C. e.: m.e.gillman@columbia.edu 
ensayo busca la apertura de vías de investigación por los especialistas de diferentes disciplinas.

Palabras clave

Economía - comercio; Marfil - comercio; Atlántico nórdico; Odobenus rosmarus; Río Volga; khutu. 
«No part of the world, to our modern way of thinking, stands any longer in rigid isolation; lands and peoples of the farthest Thule draw nearer and nearer and join into the general frame of history.»-Berthold Laufer (1913) ${ }^{3}$

Focusing on a pair of luxury materials, this essay offers a short story about long-distance trade during the "global» middle ages. ${ }^{4}$ It emerges as a response to two seemingly unrelated historiographic puzzles: one, the role of walrus ivory in the Norse Atlantic economy; the other, the origins of a mysterious material known in Arabic sources as khutū. Debated within distinct specializations, these seemingly intractable problems could benefit from being read against each other. In one, walrus is seen as being in economic competition with elephant; in the other, khutū is prized specifically for its distinction from the pachyderm. Brought together, they raise questions about substitutability and the relative value of materials -namely ivories- in different regions of the medieval world.

Navigating multiple geographies and discourses, both humanist and socialscientific, this story remains in many respects speculative. ${ }^{5} \mathrm{I}$ begin by examining the Norse problem in relationship to the morphological properties of various ivories. The lessons learned from materiality stand to revise our relationship to textual sources. In the second section, I therefore turn to khutū and the limits of philology in identifying its source. Bringing both threads into dialogue in section three, I consider networks of long-distance trade and practices of material substitution. Having but skimmed various aspects of ivory in the oikoumene between approximately the $9^{\text {th }}$ and $\mathrm{I} 6^{\text {th }}$ centuries, the conclusion spells out paths for future work.

\section{MATERIALITY \& NORSE COLONIZATION}

Around the 790s, Scandinavian Norse began raiding the British Isles, intensifying their efforts by the mid- $9^{\text {th }}$ century. After a brief period of integration and Christianization, westward attacks resumed in the closing decades of the $10^{\text {th }}$ century. During this latter phase, the Norse began expanding northward into the Atlantic,

3. LAufer, Berthold: «Arabic and Chinese Trade in Walrus and Narwhal Ivory», T'oung Pao 14, 3 (1913), 347.

4. The idea of a global middle ages has gained traction in recent years. One of the earliest formulations was that of «world-systems theory» deployed in ABU-LUGHOD, Janet: Before European Hegemony: The World System, A.D. 1250-1350. New York, Oxford University Press, 1989. Yet the «global» has also been studied in a variety of periods from antiquity to the present; see, for example, PECK, Amelia (ed.): Interwoven Globe: The Worldwide Textile Trade, 1500-1800, New York: Metropolitan Museum of Art, 2013; ArUz, Joan. «Art and Networks of Interaction across the Mediterranean», in ARUZ, Joan, Graff, Sarah B., and RAKIC, Yelena (eds.): Assyria to Iberia at the Dawn of the Classical Age. New York, Metropolitan Museum of Art, 2014, 112-24; and the essays in CASID, Jill H. and D'souzA, Aruna (eds.): Art History in the Wake of the Global Turn. Williamstown, Clark Art Institute, 2014. Collectively, these studies would seem to suggest that globalism's opposite (for which there may not be exactly one word but several -localism, isolationism, and so forth) is instead a historical exception; alternatively, or additionally, this might point toward the cheapness of the term's application.

5. This negotiation of disciplinary boundary-crossing is also explicated in MICHAILIDIS, Melanie: «Samanid Silver and Trade along the Fur Route», Medieval Encounters 18 (2012), 316-17. Michailidis focuses on the direct exchange between the Samanids and Scandinavia along the Volga, namely involving textiles and silver; we can nevertheless situate this «Fur Route» within other outlying paths of exchange -here, connecting to the Atlantic. 


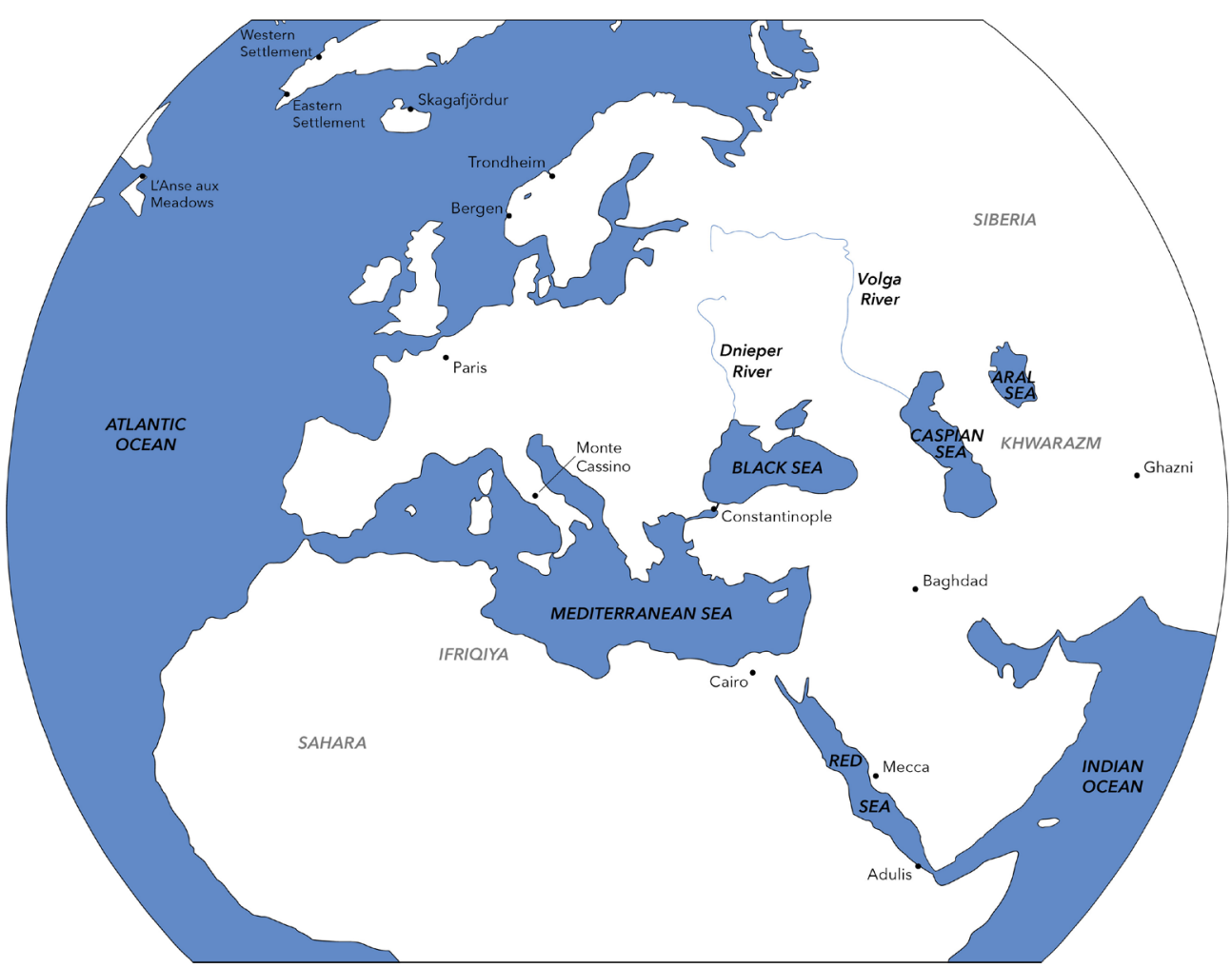

figure 1. vertical perspective map of The Medieval world. Image: Catherine Colford and Matthew Elliott Gillman.

particularly to Iceland. From there, they continued on to establish two settlements in Greenland, beginning around 985, and another in Vinland, today's Newfoundland (Figure I). ${ }^{6}$ Scholars, for at least two decades, have posited walrus hunting for trade in its ivory as a primary motivation for the colonization of Greenland. This leads to a secondary problem, regarding their subsequent collapse sometime in the $15^{\text {th }}$ century. Although an early theory attributed decline to Eskimo attacks, a second wave of scholarship made an economic argument: that an influx of elephant ivory into continental Europe in the later middle ages caused a walrus ivory price drop; this in turn made the transatlantic enterprise, dependent largely upon imported supplies, uneconomical. ${ }^{7}$

In the past few years, on the basis of new archaeology and re-readings of textual evidence, a third wave of scholarship has emerged, tending toward more nuanced

6. For an overview of Norse/Viking history, see ForTE, Angelo, Oram, Richard and Pederson, Frederik: Viking Empires. Cambridge and New York, Cambridge University Press, 2005.

7. I have unfortunately not hitherto been able to trace the exact origin of the ivory thesis in Norse histot riography. On one hand, a number of studies are in languages outside my competence (such as Danish); on the other, many citations are nested -one author citing a certain author who, when checked, in turn cites someone else, deferring the ultimate authority of the claim. On the question of elephant ivory competition, see comments by Arneborg, Jette: «The High Arctic 'Utmark' of the Norse Greenlanders», in Andersson, H., ERSGARD, L., and Svensson, E. (eds.): Outland Use in Preindustrial Europe. Lund, Institute of Archaeology, 1998; who in turn cites a 1995 study by Else Roesdahl. 
albeit still tentative explanations for Greenland's demise. Rather than pinning it on a single cause, scholars now favor an interrelated complex of factors, including climate change and emigration. Although the settlements are seen by some as economically self-sufficient, the ivory thesis continues to be included among possible components. ${ }^{8}$ Kirsten Seaver has suggested that a supply-side decrease, initiated by the settlers themselves, meant that walrus retained or even gained luxury value in the $14^{\text {th }}$ and $15^{\text {th }}$ centuries. ${ }^{9}$

Left unexamined in these discussions (which seem partially to hinge on the settlers' agency or lack thereof) is the underlying proposition about import competition in Europe. In the medieval era, the supply of elephant ivory was controlled by Muslim dynasties in North Africa, whom scholars claim retained the 'preferable' material for themselves. ${ }^{\text {Io }}$ This left Europeans with a supposedly substandard substance: walrus. Yet artists in the Eastern Mediterranean and Central Asia, despite having access to elephant, also used walrus ivory. Allowing -for the purposes of this paper- the reality of a late medieval increase in elephant ivory in Europe, its effects would not have been so clear-cut in inter-regional trade. ${ }^{\text {II }}$ To use modern economic parlance, I would posit that elephant and walrus ivory were not perfectly substitutable commodities. ${ }^{\text {I2 }}$ By this, I mean that consumers of raw ivory -whether artisans or, in some cases, collectors of exotica- were at least partially non-responsive to price changes due to perceptions of differentiation between the two goods.

At present, there seem to be too few data-points available to reconstruct the cost of walrus ivory over time. We know, for example, that in the late $1320 \mathrm{~s}$, a $300 \mathrm{~kg}$ load of walrus ivory was sold for IIkg of silver. ${ }^{13}$ It is unclear, however, whether this is a decline from a century before. Nevertheless, the material's continued use into the early modern period betrays ongoing economic opportunity. After the $15^{\text {th }}$ century,

8. Berglund, Joel: «The Decline of the Norse Settlements in Greenland», Arctic Anthropology 23, nos. 1-2 (1986), 109-35; DUGmore, Andrew J. et al.: «Cultural adaptation, compounding vulnerabilities and conjunctures in Norse Greenland», Proceedings of the National Academy of Sciences 109, 10 (2012), 3658-63; LYNNERUP, Niels: «Endperiod Demographics of the Greenland Norse», Journal of the North Atlantic 7 (2014), 18-24; Frei, K. M. et al.: «Was it for Walrus? Viking Age settlement and medieval walrus ivory trade in Iceland and Greenland», World Archaeology 47, 3 (2015), 439-66; ARNEBORG, Jette: «Norse Greenland - research into abandonment», in KRISTIANSEN, Mette Svart, Roesdahl, Else, and Graham-Campbell, James (eds.): Medieval Archaeology in Scandinavia and Beyond: History, trends and tomorrow. Aarhus, Aarhus University Press, 2015, 257-71. Keller, Christian, while sitting within this same trend of reassessment, has an alternative take that involved Greenlanders shifting voluntarily from ivory to stockfish as a main export; see «Furs, Fish, and Ivory: Medieval Norsemen at the Arctic Fringe», Journal of the North Atlantic 3 (2010), 1-23.

9. SeAVer, Kirsten A.: «Desirable Teeth: The Medieval Trade in Arctic and African Ivory», Journal of Global History 4, 2 (2009), 276-82.

10. For a brief review, see GABORIT-CHOPIN, Danielle: «Le commerce de l'ivoire en Méditerranée durant le Moyen Âge», Bulletin Archéologique 34 (2008), esp. 26.

11. For an analysis of this uptick, see GUÉRIN, Sarah M.: «Avorio d'ogni regione: The Supply of Elephant Ivory to Northern Europe in the Gothic Era», Journal of Medieval History 36 (2010), 156-74.

12. A textbook definition gives the example of nickels and dimes as perfect substitutes: as long as an individual receives one dime in exchange for two nickels, or vice versa, the exact assortment of change one has (e.g. two dimes; four nickels; or one dime and two nickels) makes no difference. In the case of other products, the exchange is usually not on parity but rather involves at least slight preference for one or the other. See MANKIW, N. Gregory: Principles of Economics, Fourth Edition. Mason, OH, Thomson South-Western, 2007, 461.

13. NøRLUnD, Poul: Viking Settlers in Greenland. Cambridge, Cambridge University Press, 1936, 99. 
the period of Greenland's demise, Russia became heavily involved in walrus ivory and the related fur trade, exporting to both Europe and the Middle East. ${ }^{\mathrm{I}}$ Given the apparent profitability of the enterprise, even in an era of wider access to elephantine ivory, this transition remains to be better analyzed.

While economic historical data is scarce on pricing structures, we can nevertheless witness imperfect substitutability by indirect means. These include the morphological properties of ivory; artistic strategies in handling the material; and, of course, textual references. The ivory-competition thesis is reliant upon a purported trade pattern broadly without necessarily considering what happened in the destination market at the level of the object. This latter approach is predicated upon attention to materiality, first deployed by Anthony Cutler and Arthur MacGregor in the mid-I980s and which has since gained ground in the analysis of artistic production methods. ${ }^{15}$

Yet studies of ivory qua raw material, particularly non-elephantine varieties, remain predicated upon generalist guides, like Benjamin Burack, and early anthropological studies. ${ }^{16}$ Meanwhile, scientific investigation into the underlying structure of the material remains ongoing. ${ }^{17}$ Publications on the visual and experimental differentiation of ivory's geographic and zoological sources has emerged from a presentist and legalistic anti-poaching framework, though its results are applicable elsewhere.$^{18}$ New techniques remain, however, under-exploited. Among these include Raman spectroscopy, capable of identifying species, and isotopic analysis, for differentiating geographic origin through trace minerals. ${ }^{19}$ Although deployed as part of excavations at Norse sites, such archaeometric techniques have not been

14. LaUfer, Berthold: «Arabic and Chinese Trade...» 337-38; CAmmanN, Schuyler V. R.: «Carvings in Walrus Ivory,» University Museum Bulletin 18, 3 (1954), 13-14.

15. Cutler, Anthony: The Craft of Ivory: Sources, Techniques, and Uses in the Mediterranean World, A.C. 2001400. Washington, DC, Dumbarton Oaks, 1985; MACGregor, Arthur: Bone, Antler, Ivory \& Horn: The Technology of Skeletal Materials since the Roman Period. London, Croom Helm, and Totowa, NJ, Barnes \& Noble, 1985.

16. BURACK, Benjamin: Ivory and its Uses. Rutland, VT and Tokyo, Charles E. Tuttle, 1984, published shortly preceding Cutler and MacGregor which, although taking more of a connoisseurial-collecting approach, likely partakes of a similar interest in the material at the time. For citations thereof, c.f. SHALEM, Avinoam: The Oliphant: Islamic Objects in Historical Context. Leiden and Boston, Brill, 2004, 14-17; HoLLoweLL, Julie: «Ancient Ivories in a Global World,» in Fitzhugh, William W., Crowell, Aron L., and Hollowell, Julie (eds.): Gifts from the Ancestors: Ancient Ivories of Bering Strait. New Haven and London, Yale University Press, 2009, 252; among others.

17. SINGH, Rina Rani et al:: «Using Morphometric and Analytic Techniques to Characterize Elephant Ivory», Forensic Science International 162 (2006), 144-51; LOCKE, Michael: «Structure of Ivory», Journal of Morphology 269 (2008), 423-50.

18. EsPINOZA, Edgard O. and MANN, Mary-Jacque: Identification Guide for Ivory and Ivory Substitutes. Washington, DC, World Wildlife Fund, 1992; MANN, William R. and MARTS, Charles M.: Ivory Identification: A Photographic Reference Guide. Temple Hills, MD, Ivorymann Publishing, 2013. Many experimental studies of ivory are forthright about this commitment; see, for example, YıN, Zuowei et al:: «A Comparison of Modern and Fossil Ivories Using Multiple Techniques», Gems \& Gemology 49, 1 (2013), 16-27.

19. VAN DER MERWE, N. J. et al.: «Source-Area Identification of Elephant Ivory by Isotopic Analysis.» Nature 346 (1990), 744-746; TAKEUCHI, T., NAKANO, Y., and KOIKE, H.: «Neutron Activation Analysis of Ivory of African Elephants», Journal of Radioanalytical and Nuclear Chemistry 205, 2 (1996), 301-309; BuRRAGATO, F. et al.: «New Forensic Tool for the Identification of Elephant or Mammoth Ivory», Forensic Science International 96 (1998), 189-96; Shimoyama, Masahiko, Morimoto, Susumu, and Ozakı, Yukihiro: «Non-destructive analysis of the two subspecies of African elephants, mammoth, hippopotamus, and sperm whale ivories by visible and short-wave near infrared spectroscopy and chemometrics», Analyst 129 (2004), 559-63; BANERJEE, Arun: «Non-Destructive Investigation of Ivory by FTIR and Raman Spectroscopy», in BüHL, Gudrun, CUTLER, Anthony, and EfFenberger, Arne (eds.): Spätantike und byzantinische Elfenbeinbildwerke im Diskurs. Wiesbaden, Reichert Verlag, 2008, 1-7. 


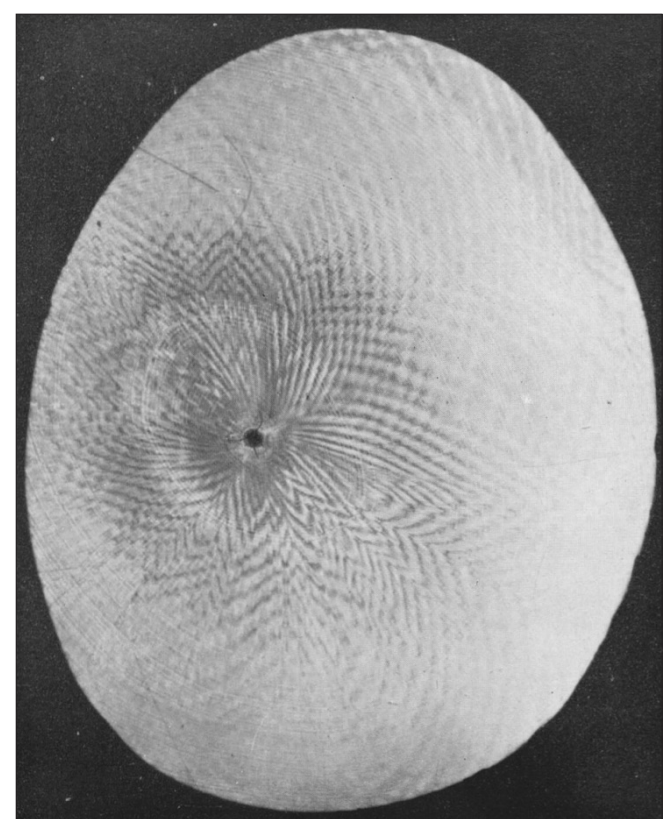

FIGURE 2A. TRANSVERSE SECTION PHOTOGRAPH OF elephant IVORY. Image: Penniman, T.K.: Pictures of Ivory (1952), Plate I, by permission of the Pitt Rivers Museum, Oxford.

routinely applied in museum settings..$^{20}$ Only in recent years have some publications, such as the Victoria \& Albert Museum's three-volume catalog of medieval ivories, chosen to attribute a zoological source for works in ivory. ${ }^{21}$ Nevertheless, a comparative, morphologically minded approach, enriched by such studies, can be brought to bear even in reevaluating textual sources (as in the subsequent section).

Unqualified, the word «ivory» today brings to mind elephant tusks. Although the Latin ebur referred exclusively to this kind in antiquity, later European vernaculars as well as the Arabic and Persian 'a $j$ were ambivalent. ${ }^{22}$ Even among elephants, there were three distinct species in Africa -the Forest, Savannah, and North African Elephants- as well as the Asian Elephant. ${ }^{23}$ The North African variety went extinct in late antiquity -a result not of poaching for ivory, as is the threat today, but rather due to their use in sport. ${ }^{24} \mathrm{~A}$ fifth variety of proboscidean ivory derives from the extinct mammoth, whose remains are still found preserved in the Siberian tundra. ${ }^{25}$ All share a number of characteristic features, including patterns of regularly intersecting lines, seen in section, referred to as a «Schreger pattern» (Figure 2A). ${ }^{26}$

Whether medieval Europe relied upon primarily an African species or the Asian one is a matter of conflicting opinion. Ralph Pinder-Wilson claimed it was «unlikely that India exported ivory in any quantity to the Near East or Europe as it scarcely produced enough for its own needs. ${ }^{27}$ Diana Rowan has argued the opposite, that «around the time of Christ, India replaced Africa as the primary source of ivory in the West, a fact substantiated by frequent reference to ebur indicum by Latin

20. FREI, Karin et al:: «Was it for Walrus?,» 448-57. Although analyzing bone material, see as precedent the work by HARrison, Ramona, Roberts, Howell M., and AdderLEV, W. Paul: «Gásir in Eyjafjörđur: International Exchange and Local Economy in Medieval Iceland», Journal of the North Atlantic 1 (2008), 99-119.

21. Williamson, Paul: Medieval Ivory Carvings: Early Christian to Romanesque. London, V\&A Publishing, 2010; Williamson, Paul and Davies, Glyn: Medieval Ivory Carvings: 1200-1550, 2Vv. London, V\&A Publishing, 2014.

22. Among other authors, Pliny THE Elder mentions the material in his Natural History, Volume III: Books 8-11. Trans. RACKHAM, Harris. Cambridge, MA, Harvard University Press, 1940, 7, 25. For a general outline of antique ivory, see GILL, D. W. J.: «The Ivory Trade», in FITTON, J. Lesley (ed.): Ivory in Greece and the Eastern Mediterranean from the Bronze Age to the Hellenistic Period. London, British Museum, 1992, 233-37. As Shalem, Avinoam, Op. cit. 13-14, notes, the term 'áj seems to refer metonymically to the bend in the tusk, whereas there is also a more specific term for «elephant teeth» (näb al-fïl).

23. «Family Elephantidae,» in KINGDON, Jonathan (ed.): Mammals of Africa, vol. 5. London, Bloomsbury, $2013,176$.

24. Cutler, Anthony. The Craft of Ivory. 23-24.

25. Burack, Benjamin, Op. cit. 30; MacGregor, Arthur, Op. cit. 40.

26. These are named after naturalist Bernhard Gottlieb Schreger (d. 1825); see LoCKE, Michael, Op. cit. 430-33.

27. PINDER-WILSON, Ralph: «'Ā $\bar{d} j$.» Encyclopedia of Islam, online. 


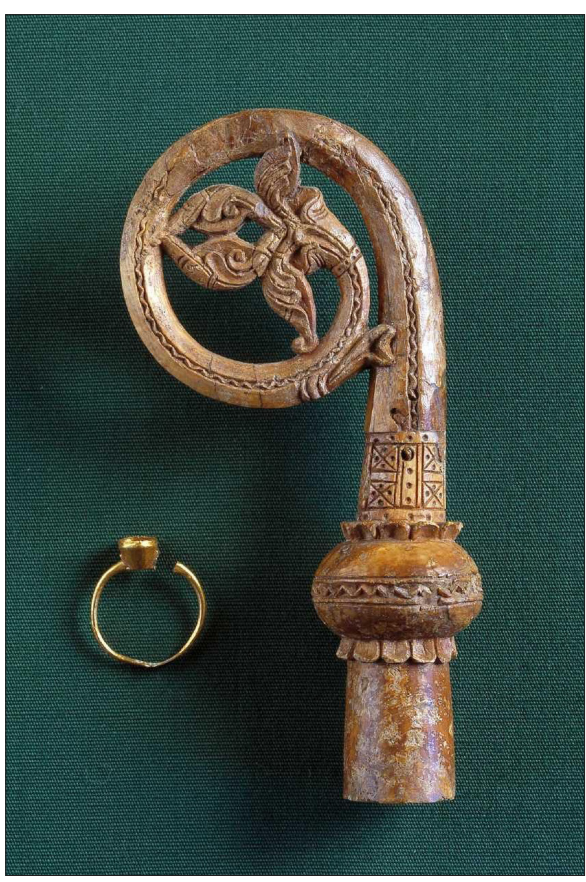

FIGURE 3. GARĐAR CROZIER FOUND IN THE EASTERN SETTLEMENT. WALRUS IVORY. NATIONALMUSEET (COPENHAGEN), (CAT. N ${ }^{\circ}$ D11154). Image: Lennart Larsen/Nationalmuseet (CC-BY-SA).

authors. $\aleph^{28}$ Each makes recourse to a I9 ${ }^{\text {th }}$ century author for their claim. ${ }^{29}$ Confusing matters is evidence for an apparent trade in ivory between Africa and India..$^{\circ}$ This trade could, perhaps, relate to the Asian elephant's use as a war machine, precluding its conscription for artistic purposes. Even when so used, the tusks of the different species have variations, particularly in size. Cutler notes that Indian ivory tends to be narrower in diameter; short of experimental identification, objects above a certain girth are likely to be of African origin. ${ }^{31}$

Whereas elephant ivory had been used since antiquity, walrus was a relative newcomer. Although some exceptional artifacts survive from the $7^{\text {th }}$ century or even earlier, ${ }^{32}$ the material is first attested textually through the oft-quoted Norwegian sailor Ohthere in $890 . .^{33}$ The use of walrus ivory in Middle Eastern art around this time has been little examined, likely due to scant physical evidence. ${ }^{34}$ It has been suggested, perhaps tenuously, that the material was already known to the Sasanian dynasty (224-65I) in Persia. ${ }^{35}$ At the very least, it arrived sometime in the early years of Abbasid rule (750-I258).

Whether or not ivory was the primary motivator for the establishment of the Greenland settlements at the end of the Io $^{\text {th }}$ century, there is clear evidence of walrus hunting taking place there..$^{36}$ Commercial ivory from Greenland was probably distributed to continental Europe through Bergen; other tusks paid as in-kind tithes transited Trondheim. ${ }^{37}$ With the exception of the so-called Garðar Crozier (Figure 3), ivory

28. Rowan, Diana P.: «Reconsideration of an Unusual Ivory Diptych», Artibus Asiae 46, 4 (1985), 252. NB: I have here interpolated a comma between «Christ» and «India.»

29. Pinder-Wilson, Ralph, Op. cit., cites, Heyd, W.: Histoire du commerce du Levant au Moyen Age. Leipzig, Harrassowitz, 1886, 629-30; RowAN, Diana, Op. cit. 252, n. 6, cites the entry of JACOB, Alfred: «Ebur», in Dictionnaire des antiquités grecques et romaines. Paris, Hachette, 1892.

30. Cosmas Indicopleustès: Topographie chrétienne, Tome III. WolskA-Conus, Wanda (trans.): Paris, Les Éditions du Cerf, 1973, 352-55.

31. Cutler, Anthony. The Craft of Ivory. 27-28.

32. Roesdahl, Else: «Walrus ivory - demand, supply, workshops, and Greenland», in MortenSEN, Andras and ARGE, Símun V. (eds.): Viking and Norse in the North Atlantic: Selected Papers from the Proceedings of the Fourteenth Viking Congress. Tórshavn, Føroya Fróðskaparfelag, 2005,184; ROESDAHL, Else: «L'ivoire de morse et les colonies norroises», Proxima Thulé 3 (1998),17.

33. Lund, Niels (ed.) and FelL, Christine E. (trans.): Two Voyagers at the Court of King Alfred. York, William Sessions Limited, 1984, 18-22.

34. Shalem, Avinoam, Op. cit. 30.

35. FrEI, Richard N.: «Byzantine and Sasanian Trade Relations with Northeastern Russia», Dumbarton Oaks Papers 26 (1972), 266; ChOKsy, Jamsheed K.: «Sassanians,» in BoWersock, G. W., Brown, Peter and Grabar, Oleg (eds.): Late Antiquity: Guide to the Postclassical World. Cambridge, MA, Belknap Press, 1999, 682-83.

36. An overview is offered in FREI, Karin et al. «Was it for Walrus?...» 445-48.

37. Pierce, Elizabeth: "Walrus Hunting and the Ivory Trade in the North Atlantic», in CaldWelL, David H. and Hall, Mark A. (eds.): The Lewis Chessmen: New Perspectives. Edinburgh, National Museums Scotland, $2014,177$. 
does not appear to have been worked in Iceland or Greenland, only exported as a raw material; a handful of finished works, also croziers, were nevertheless reimported..$^{8}$

Contrary to Atlantic historiography, it does not appear that elephant and walrus were treated similarly in the market or workshop. Only a handful of applications used both types -particularly small items such as gaming pieces. In other types of works, we tend to find one or the other. Freestanding sculpture, for example, seems invariably elephantine; sword and knife handles, on the other hand, are most often made with walrus. This difference was also partly regional: the former (alongside other devotional objects such as portable altars) a European tendency; the latter, a Middle Eastern one. There are nevertheless some exceptions to this characterization, such as a walrus knife handle found in a metalsmith's workshop in Perth. Stratigraphically datable to the early $\mathrm{I}^{\text {th }}$ century, its relative lateness provides a counterexample to the European (re)adoption of elephant ivory. ${ }^{39}$

There are three main features that distinguish the two varieties and, thereby, their possible subsequent uses. The subtlest one regards profile, in that elephant tusks appear circular in section, whereas walrus are oval. A second, more limiting feature is size: Whereas elephant tusks can reach lengths of nearly $3.5 \mathrm{~m},{ }^{40}$ this is the length of a walrus' entire body. ${ }^{4 \mathrm{I}}$ The latter's tusks are instead about one-half to three-quarters of a meter. ${ }^{42}$ For reductive sculptural processes, this poses a physical limit on possible works. An alternative, using additive processes to make a larger object, was in some instances circumscribed by law. A set of $13^{\text {th }}$ century Parisian guild regulations compiled by Étienne Boileau, Le livre des métiers, specified that sculptors (ymagiers tailleurs), with only a couple of exceptions, had to work in a single piece rather than joining. ${ }^{43}$ This is not to say that some artists did not do so;44 in one peculiar example, the Herlufsholm Christ, the body is made of one piece of elephant ivory with attached arms of walrus. ${ }^{45}$

A final distinction, key for the subsequent discussion, involves the interior structure. Elephant and mammoth share the aforementioned Schreger pattern. This is absent from walrus, which is instead characterized by an outer layer of «plain» ivory and an inner, granular core of so-called secondary dentine or osteodentine, which

38. Pierce, Elizabeth, Op. cit. 178; Pórarinsson, Guðmundur G.: «The Lewis Chessmen: The Icelandic Theory», in CALDWelL, David H. and Hall, Mark, A.: Op. cit. 208-209.

39. HALL, M. A.: «An Ivory Knife Handle from the High Street, Perth, Scotland: Consuming Ritual in a Medieval Burgh», Medieval Archaeology 45 (2001), 169-88.

40. «Family Elephantidae,» in KINGDON, Jonathan, Op. cit. 177.

41. RAY, G. Carleton: «Walrus, the Beringian 'Tooth-Walker,'» in FitzHugh, William W., CROWELL, Aron L. and HollowelL, Julie (eds.): Gifts from the Ancestors: Ancient Ivories of Bering Strait, (New Haven and London: Yale University Press, 2009), 46.

42. Cammann, Schuyler V. R., Op. cit. 3; Ray, G. Carleton, Op. cit., loc. cit.

43. Translated and cited by SEARS, Elizabeth: «lvory and Ivory-Workers in Medieval Paris», in BARNET, Peter (ed.): Images in Ivory: Precious Objects of the Gothic Age. Detroit, Detroit Institute of Arts; Princeton, Princeton University Press, 1997, 21.

44. LeVINE, Adam Harris: «Putting Together the Pieces: Composite Techniques in Gothic Ivories», The Sculpture Journal 23, 1 (2014), 41-50.

45. Davies, Glyn and GUÉRIN, Sarah: «Introduction», The Sculpture Journal 23, I (2014), 10; NYBORG, Ebbe: «The Beginnings of Gothic Ivory Sculpture: Recent Discoveries in a Group of Danish Ivories», The Sculpture Journal 23, 1 (2014), 31. 


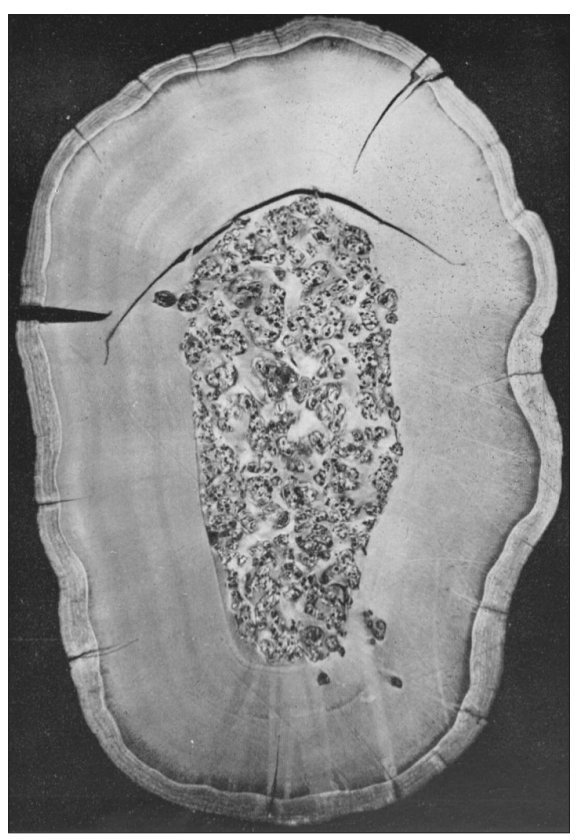

FIGURE 2B. TRANSVERSE SECTION PHOTOGRAPH OF WALRUS IVORY. Image: Penniman, T. K., Pictures of Ivory (1952), Plate VIII, by permission of the Pitt Rivers Museum, Oxford. has a mottled, reddish appearance (Figure 2B). ${ }^{6} 6$ Within European art history, it is an open question whether or not this substance was a desirable or lamentable aspect, something to be revealed or concealed. Meanwhile, Middle Eastern contexts suggest both possibilities, depending on the period and places. Although there are a plethora of examples from the early modern period, the paucity of surviving medieval objects makes it difficult to assess whether these represent a continuity with or departure from earlier practices.

The earliest extant Islamic ivories, which are elephantine, originate from the Abbasid residence at Humayma, likely predating the family's political ascendance in the mid- $8^{\text {th }}$ century ${ }^{47}$ Better-known medieval works are the pyxes and caskets produced at the Umayyad court in al-Andalus (though others were produced in the Islamic East) as well as oliphants, variously attributed to Egypt, Sicily, and southern Italy. Three of the earliest comparanda for walrus-hilt edged weapons are at the Furusiyya Art Foundation. One is the partially calcified hilt of a Sicilian short-sword, considered $\mathrm{I} 2^{\text {th }}$ or $\mathrm{I} 3^{\text {th }}$ century. ${ }^{48}$ This is predated by two small ivory knife hilts, one with preserved blade, which are of alleged Afghan provenance and attributed to the $\mathrm{IO}^{\text {th }}$ to $\mathrm{I}^{\text {th }}$ century. ${ }^{49}$

There is then a temporal and spatial gap in evidence before the early modern appearance, en masse, of ivory objects in the Ottoman, Safavid, Mughal, and Qajar realms. A curved sword (Turkish yatağan), produced by Ahmad Tekelü in a Constantinopolitan court workshop around the I520s, has a single-piece walrus ivory pommel. Its osteodentine is partially interrupted by a silver gilt boss which may constitute part of a structurally necessary peen block (Figure 4)..$^{50}$ Even with the inclusion of gold floral scrolls and two inset rubies, the granular center remains visible rather than concealed. Later Ottoman yatağans were constructed instead of bifurcated pommels with plates of various materials, including walrus. One example, produced in I864-65 for a certain Mustafa Ağa, readily reveals the mottling

46. LOCKE, Michael: «Structure of Ivory», Journal of Morphology 269 (2008), 444. He attributes the term «secondary dentine» to ESPINOZA, Edgard O. and MANN, Mary-Jacque. Identification Guide for lvory and lvory Substitutes. Washington, DC, World Wildlife Fund, 1992, although the description goes back to Cammann in the 1950s, if not earlier; c.f. «Carvings in Walrus Ivory», 4.

47. Foote, Rebecca M.: «Frescoes and Carved Ivory from the Abbasid Family Homestead at Humeima», Journal of Roman Archaeology 12 (1999), 423-29.

48. Mohamed, Bashir: The Arts of the Muslim Knight: The Furusiyya Art Foundation Collection. Milan, Skira, 2008, 40-41, cat. $\mathrm{n}^{\circ}$. 10.

49. Mohamed, Bashir, Op. cit. 149, cat. nos. 141 and 142.

50. For a description, see AleXANder, David G.: Islamic Arms and Armor in the Metropolitan Museum of Art. New York: Metropolitan Museum of Art, 2015, 152-54, cat. $n^{\circ}$ 57. «lvory» is noted in the material list but «walrus ivory» specified in the formal description. 


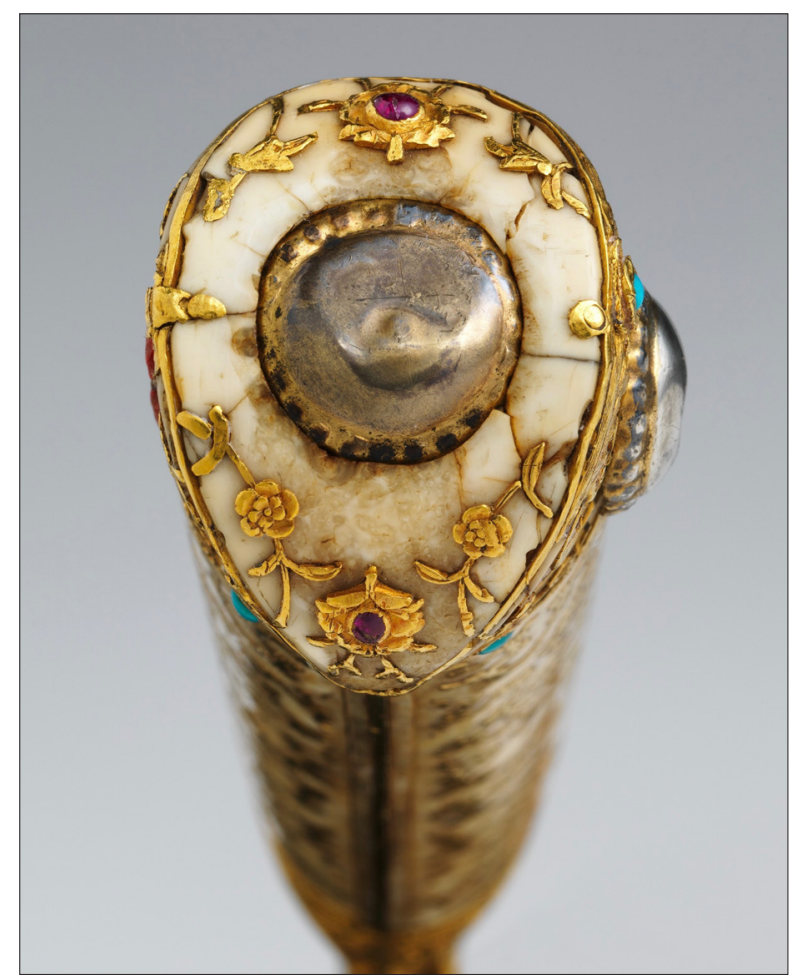

FIGURE 4. DETAIL OF AN OTTOMAN YATAĞAN FROM THE WORKSHOP OF AHMED TEKELÜ, CA. 1525-30. STEEL, WALRUS IVORY, GOLD, SILVER, TURQUOISE, PEARL, AND RUBY. METROPOLITAN MUSEUM OF ART (NEW YORK, NY), PURCHASE, LILA ACHESON WALLACE GIFT, (ACC. NO 1993.14). Image: Public Domain (CCO). in the oversized lobes which, when worn in a belt, would have been on display (Figure 5). ${ }^{51}$

Meanwhile, the Persian treatment of the material seems to downplay or even avoid the osteodentine. An early example is a sword roughly contemporaneous to the Tekelü example, made for Shah Tahmasp (r. I524-76) and now at the Victoria \& Albert Museum. It consists of two thin, double-spiraled walrus plaques framed by plain metal shims. ${ }^{22}$ Appearing creamy white, it could pass as elephantine. Later, Qajar-era daggers instead do reveal a more or less intense reddish coloring. ${ }^{53}$ Another extant example in London, produced by Muhammad Hādī in I798, appears to work primarily with the walrus tusk's core, producing an even, subdued mottling. ${ }^{54}$

\section{PHILOLOGY \& EURASIAN TRADE}

To be fair, these aesthetic and economic differences would not be immediately surmised by reading contemporary sources, which instead employ confused terminology and understandings of the materials. This has in turn possibly limited the scope of modern discussion. Here, we can use the example of the Arabic and Persian khutū. Although not appearing in European languages, it is attested in a number Chinese texts (as $k u$ tu hsi), where it is sometimes believed to be the skull of a «thousand-year snake. $\rangle^{55}$ Our main source on the subject is the lapidary of al-Bīrūnì (d. I048), The Book Most Comprehensive in Knowledge of Precious Stones (Kitāb al-jamāhir fī ma 'rifat al-jawāhir). ${ }^{56}$ He notes its animal rather

51. This particular example is previously unpublished and its source of acquisition unknown; for a comparable piece in print, one dated 1280/1863-64, see AlEXANDER, David: The Arts of War: Arms and Armour of the 7th to 19th Centuries. London, Nour Foundation, 1992, 116-17, cat. n 62. Bošković, Dora: Zbinka Jatagana u Hrvatskom Povijesnom Muzeju u Zagrebu. Zagreb: Hrvatski Povijesni Muzej, 2006, a catalog of yatağans with bilingual essay and Croatian entries providing a substantial corpus of such weapons, does not distinguish between bone, elephant ivory, and walrus ivory.

52. London, Victoria \& Albert Museum, $n^{\circ} .3378($ IS).

53. For published examples, see AlLAN, James and Gilmour, Brian: Persian Steel: The Tanavoli Collection. Oxford, Oxford University Press, 2000, 151-53, Pls. A.8-A.10. These three objects, incidentally, are labeled only as «ivory» rather than walrus ivory; c.f. comments pertaining to n. 21, above.

54. London, Victoria \& Albert Museum, $n^{\circ} .715-1889$.

55. Laufer attempts to place the origin of the Chinese word in a Tungusic language; yet, as he also notes, this would be coeval with al-Biruni's writing. The origin of the word therefore remains unclear. See LAUFER, Berthold. «Arabic and Chinese Trade...», 318-19.

56. I have frequently modified the English translation -Bīrūnī, Muhammad ibn Aḥmad: The Book Most Comprehensive in Knowledge on Precious Stones, trans. H. M. Said (Islamabad: Pakistan Hijra Council, 1410/1989)- by consulting an edition of the Arabic text, namely BīrūNī, Muḥammad ibn Aḥmad: Al-jamāhir fĩ al-jawāhir. ed. Yūsuf al-Hādī, Iran: Sharikat al-Nashr al-'Ilmī wa'l-Thaqāfī, 1995. 


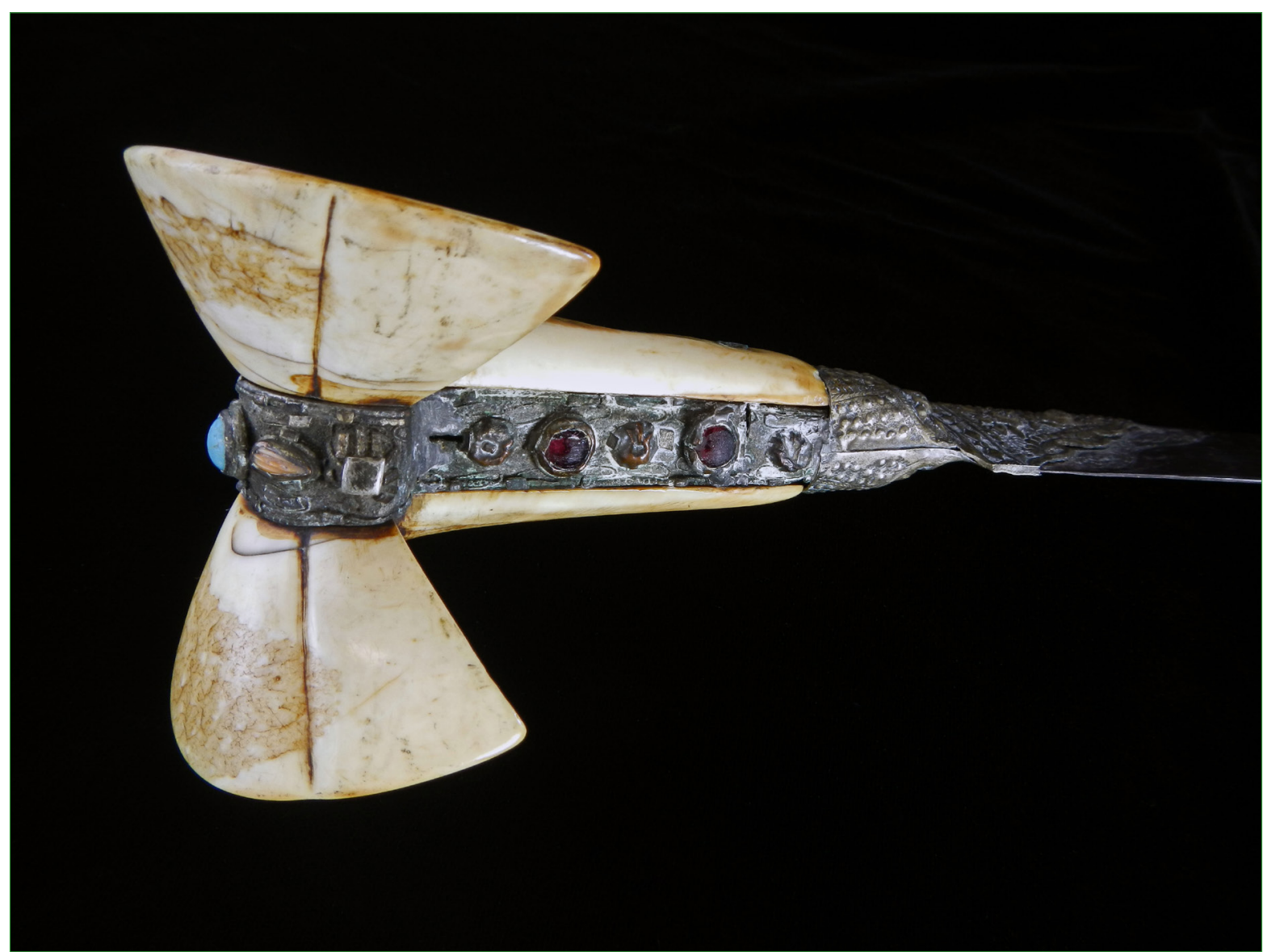

FIGURE 5. DETAIL OF AN OTTOMAN YATAĞAN DATED 1281/1864-65. STEEL, WALRUS IVORY, TURQUOISE, CORAL, AND RUBY-COLORED GLASS. WASHINGTON STATE HISTORICAL SOCIETY (TACOMA, WA), CAT. N . 3853. Image: By permission of the Washington State Historical Society).

than mineral origin as well as the idea that it quivers or sweats in the presence of poisoned food. ${ }^{57}$ He claims to have met with some Chinese ambassadors (al-rusul alwäridina min qitä $\bar{\imath}$ ), who noted that this property was the material's main interest.

Following this is a brief discussion of competing claims about khutū 's geographic and zoological origins. The ambassadors claimed it came from the «forehead of a bull,» which Bīrūni took to mean a certain species of Kyrgyz mountain goat. (This has been reprised by a pair of modern scholars, who non-exclusively associate the material with the musk-ox..$\left.^{8}\right)$ Bīrūnī himself disbelieved this, instead suspecting a marine origin.$^{59} 20^{\text {th }}$ century scholars have in turn offered various possibilities, namely elephant (viz. the Asian species), walrus, and frozen mammoth. ${ }^{60}$ Some have

57. Bīrūnī, On Precious Stones, 180.

58. Lavers, C. and KNAPP, M.: «On the origin of khutū», Archives of Natural History 35, 2 (2008), 313-15. This hypothesis is, by their own admission, rather difficult -although the animal fits al-Bīrūnīs description, it had been long extinct in Eurasia and was instead only found in North America (The species has since been reintroduced in modern times.) Their suggestion of a possible trade across the Bering Strait is intriguing and, if true, could be linked to Central Asia via Korea and China; see p. 95, below.

59. BīrūNī, Al-Jamāhir fĩ al-jawāhir, 338-341.

60. LAUFER, Berthold. «lvory in China», 32-33, 53-56 
also associated it with the idea of the unicorn, which animal Richard Ettinghausen linked to the rhinoceros (karkadan). ${ }^{6}$

Bīrūnī at one point also notes, encyclopedically if dismissively, that some claimed khutū was «the forehead of a giant bird» ('azm jabhah țā'ir 'azìm jiddan). ${ }^{62}$ Today, the forehead of the Helmeted Hornbill (Rhinoplax vigil), hunted in southeast Asia, is indeed used as an ivory substitute. ${ }^{63}$ This use is attested in the late $14^{\text {th }}$ century Essential Criteria of Antiquities (Ko Ku Yao Lun), dependent on earlier Chinese sources, ${ }^{64}$ though mistaking hornbill for a fish. ${ }^{65}$ These together might help us make sense of an entry for khutū in Kāshgarì's I $^{\text {th }}$ century Compendium of the Turkish Languages (Diwān Lughät al-Türk), who noted it as «horn of a sea fish imported from China,» among other possibilities. ${ }^{66}$ One might thereby be tempted to make a connection between this bird, khutū, and even the monsoon-based maritime trade which passed through the Strait of Malacca in the $8^{\text {th }}$ and $9^{\text {th }}$ centuries, if not later. ${ }^{67}$ Although circumstantially curious, the medieval description of khutü's visual properties may preclude such a reading.

The other key reference used by today's historians regarding khutū is a I9I3 article by Berthold Laufer of Chicago's Field Museum of Natural History. Although he supplied extensive philological evidence, his interpretations thereof are sometimes problematic. Beginning from the title, he claimed that the term must apply to both walrus and narwhal ivory. ${ }^{68}$ The latter seems unlikely and its inclusion is based upon a false logic of elimination. To summarize Laufer's argument: First, the existence of words in Chinese for rhino horn and elephant or mammoth ivory means another word is not possible, since there could be no confusion over something already known. (That Arabic sources occasionally use the term «fish-teeth» for a substance which must also be walrus seems not to have posed the same difficulty to him. ${ }^{69}$ ) Second, he asserts that the "only two other creatures on this globe furnishing ivory» were walrus and narwhal; both must therefore be included..$^{\circ}$ Strangely, he does not allow for confusion with additional ivory substitutes, such as Dugong, which he relegates to a footnote. ${ }^{7^{1}}$

\footnotetext{
61. Ettinghausen, Richard: The Unicorn. Washington, DC, Smithsonian Institution, 1950, 6-11.

62. BīrūNī, On Precious Stones, 180; Bīrūnī, Al-Jamāhir fĩ al-jawāhir, 340.

63. Burack, Benjamin, Op. cit. 37.

64. CaO, Zhao: Chinese Connoisseurship: The Ko Ku Yao Lun, The Essential Criteria of Antiquities. Sir Percival David (Ed. and trans.) New York, Praeger, 1971, 125. This text, accessible to me only in translation, is a slightly problematic specimen. David worked from a 1459/1462 printing, which enlarged the 1388 text with interpolations, sometimes misquoted, from earlier works. Such, at least, was the critique leveled by WATT, J. C. Y. in his review from Journal of the Hong Kong Branch of the Royal Asiatic Society 12 (1972), 213-18. David nevertheless notes where these insertions occur.

65. CAO, Zhao, Op. cit. 130.

66. DANKOFF, Robert: «A Note on khutū and chatuq», Journal of the American Oriental Society 93, 4 (1973), 542.

67. GUY, John: «Rare and Strange Goods: International Trade in Ninth-Century Asia», in KRAHL, Regina et al. (eds.): Shipwrecked: Tang Treasures and Monsoon Winds. Washington, DC, Arthur M. Sackler Gallery, 2010, 18-27.

68. See also LAUfER, Berthold: «Arabic and Chinese Trade», 338, n. 2.

69. On the thorniness of this issue, see Ettinghausen: Op. cit. 140-41; Lavers and Knapp: Op. cit. 312-13.

70. LAUFER, Berthold. «Arabic and Chinese Trade», 329-32.

71. Idem., 350-51, n. 5. On various modern sources of ivory alternatives, see Burack, Op. cit. 28-40, supplemented by MAcGregor, Arthur, Op. cit. 41 .
} 
Yet Laufer's claim that there is no distinction between walrus and narwhal, later affirmed by Ettinghausen and Robert Dankoff, was based solely on modern commerce. ${ }^{72}$ For what medieval evidence exists, this conflation seems unsupported. Narwhal tusks do not appear to have been carved, let alone used in fragmented pieces. Instead, we tend to find the material preserved whole in church treasuries, showcasing its distinctive twisting structure. ${ }^{73}$ The main exception is a pair of English Romanesque narwhal teeth, partially carved for use as either processional staffs or candlesticks. ${ }^{74}$ (Meanwhile, the only narwhal ivory object from the Muslim world of which I am aware is an early $\mathrm{I} 7^{\text {th }}$ century Mughal archer's ring depicting Christ Pantokrator -surely an unusual specimen. ${ }^{75}$ ) Laufer hedges only at the end of his winding article, admitting «that a confusion with mammoth ivory was possible, in view of the fact» -with no evidence provided- «that it seldom was the complete tusk which was the object of trade. $\gg^{76}$ Vladimir Minorsky later noted, contra Laufer, that the Chinese and Arabic words seemed to mean different things. ${ }^{77}$

Laufer's argument rests upon a positivist logic, bordering on a kind of linguistic determinism. Claiming that language cognitively structures individual and collective experience of the world, the absence of a word indicates the absence of a concept. ${ }^{78}$ (And, conversely, a word has a one-to-one relationship to its concept.) However, since language precedes a first experience of exotica, it holds the potential to fall short in the act of description. Even with the benefit of recollection and reflection, this very befuddlement is a recurring trope in medieval ekphrasis, especially in diplomatic contexts. ${ }^{79}$ This is a real or affected failure of expression (part of the discourse of exotica), not sight and apprehension. Given ivories' long-range trade movements, we should expect a certain amount of confusion over the ontological «reality» of materials. Khutū, in other words, might simply be a word applied to a number of different materials whose zoological origins were lost in transit. «Khutū» might simply denote an eastern -that is, Siberian- origin, rather than one from the Volga trade. ${ }^{80}$

Another locale possibly involved in this trade, which seems to have escaped prior notice, may have been Korea. This again comes from comparing notes between two

72. LaUfer, Berthold. «Arabic and Chinese Trade», 337, 350; DANKoff, Robert, Op. cit. 542-43.

73. Shalem, Avinoam. 124.

74. Victoria \& Albert Museum, London, A.79-1936, and World Museum, Liverpool, 1995.42. This is in contrast to the claim by LAVERS, C. and KNAPP, M.: Op. cit. 308-309, who suggest that «the tusks [...] were probably cut up before being traded.»

75. WeLCH, Stuart Cary: India: Art and Culture, 1300-1900. New York, Metropolitan Museum of Art, 1985, 205, cat. $n^{\circ} 134$.

76. LAUfER, Berthold. «Arabic and Chinese Trade», 356.

77. Minorsky, Vladimir (ed. and trans.): Sharaf al-Zamān Tähir Marvazì on China, the Turks, and India. London, Royal Asiatic Society, 1942, 82-83.

78. A recent defense of this idea proposed that scholars have overstated and oversimplified the original cone cept; see SHARIFIAN, Farzad, «Cultural Linguistics and Linguistic Relativity,» Language Sciences 59 (2017), 83-92.

79. See, for example, the account of two Byzantine ambassadors visiting al-Muqtadir, as related in Book of Gifts and Rarities (Kitāb al-Hadāyā wa al-Tuhaf), ed. and trans. Al-QAdDūmī, Ghāda al-Hijjāwī. Cambridge, MA, Harvard Center for Middle Eastern Studies, 1996, 150-55. This idea of bewilderment is discussed, though from a different perspective, by DugGan, T. M. P.: «Diplomatic Shock and Awe: Moving, Sometimes Speaking, Islamic Sculptures», Al-Masaq: Islam and the Medieval Mediterranean 21, 3 (2009), 229-67.

80. LAVERS and KNAPP, Op. cit. 312-13. 
rather different sources. One is the anonymously composed first half of Reports on China and India (Akhbär al-Sind wa'l-Hind), an early to mid- $9^{\text {th }}$ century compendium of traveller's accounts likely produced in Iraq. It makes reference to Korea (alSilä, i.e. the Silla dynasty, 57 BCE-935 CE), noting simply that of the author's «circle of informants,» none «ever made it there and brought back a reliable report.» $\mathrm{He}$ does add a couple of small details, such as the fact that Koreans «exchange[d] gifts with the ruler of China». ${ }^{8 \mathrm{I}}$ Indeed, a century later, the Institutional History of Tang (T'ang huiyao) by Wang Pu (d. 982) noted that its eponymous dynasty had received several Korean gifts of fish-tusks in the eighth century. ${ }^{82}$

For the present purposes, it is not absolute clarification of identity but rather questions of perceived value which are important. Al-Bīrūnī, who sometimes made comments about collectors, claimed that two rulers had objects of khutü: the Saffarid Amīr Abū Ja far b. Bānū (r. 922-63), a casket; the Ghaznavid Sultān Maḥmūd (r. 998-I030), an inkwell. ${ }^{83}$ Gifts of the material to Sultān Maḥmūd are also reported in the Ornament of Histories (Zayn al-akhbār) of 'Abd al-Hayy b. Zahhạak Gardīzì (fl. mid-II ${ }^{\text {th }}$ century). ${ }^{84}$ This was situated as part of a larger exchange of presents between himself and the Qarakhanid ruler Qadir Khān (r. I026-32) in which the latter received, among other items, «ten female elephants» with fine trappings from the Sultān. ${ }^{85}$ The story suggests that, for someone with access to elephants like Sultān Maḥmūd, khutū was an appropriate counter-gift to receive.

\section{ARTIFACT AND ARTIFICE}

Aside from terms for the materials as a whole, there was also a language, somewhat opaque today, for describing tooth anatomy which has not yet been considered in understanding this puzzle. Mammoth ivory, for example, is highly variable in color depending on burial conditions. Al-Bīrūnī's reference to a low-grade, «dusty» khutū could be a reference to mammoth ivory spotted by a lichen colony. ${ }^{86}$ In another comment, he refers to shavings (nuhätah) and pith (lubb) of khutū. The latter also seems to be referred to as «the essence of the teeth» (jawhar al-sinn), which «has sword [damascening] patterns» (fï nuqūshihi al-firindìya) ${ }^{87}$ Damascening can produce either periodic or aperiodic lines in steel. This could refer to the regularly intersecting lines forming the Schreger Pattern in elephant or mammoth; the former

81. Two Arabic Travel Books (New York: New York University Press, 2014), 65.

82. Cited by SChAfER, Edward H.: The Golden Peaches of Samarkand: A Study of T'ang Exotics. Berkeley and Los Angeles, University of California Press, 1963, 242.

83. BīrūNī, On Precious Stones, 181; Bīrūnī, Al-Jamahir fiäal-jawahir, 341.

84. GARDīzì, 'Abd al-Ḥayy ibn Zahhạā: The Ornament of Histories: A History of the Eastern Islamic Lands, AD 650-1041, ed. and trans. Edmund Bosworth. London, I. B. Tauris, 2011, 94-95.

85. Ibidem.

86. On the grades of ivory, see On Precious Stones, 181; on the growth of lichens in archaeological ivory, see Edwards, Howell G. M. et al.: «Ancient Biodeterioration: An FT-Raman Spectroscopic Study of Mammoth and Elephant Ivory», Analytical and Bioanalytical Chemistry 383 (2005), 720.

87. Al-Bīrūnī, Al-Jamāhir fĩ al-jawāhir, 339; On Precious Stones, 180, gives simply «it has patterns described over it.» 
requires close inspection of a tusk cut at certain angles in order to be visible, whereas the latter's lines are sometimes emphasized by environmental condition. More likely could be osteodentine, easily visible and revealing semi-random patterns. Its use as a knife hilt would have thereby visually coordinated with the blade. Suggestively, a small number of watered-steel blades have been preserved in Afghanistan which likely date from the Ghaznavid (977-II86) or Ghurid (IOII-I2I5) period (Figure 6). ${ }^{88}$

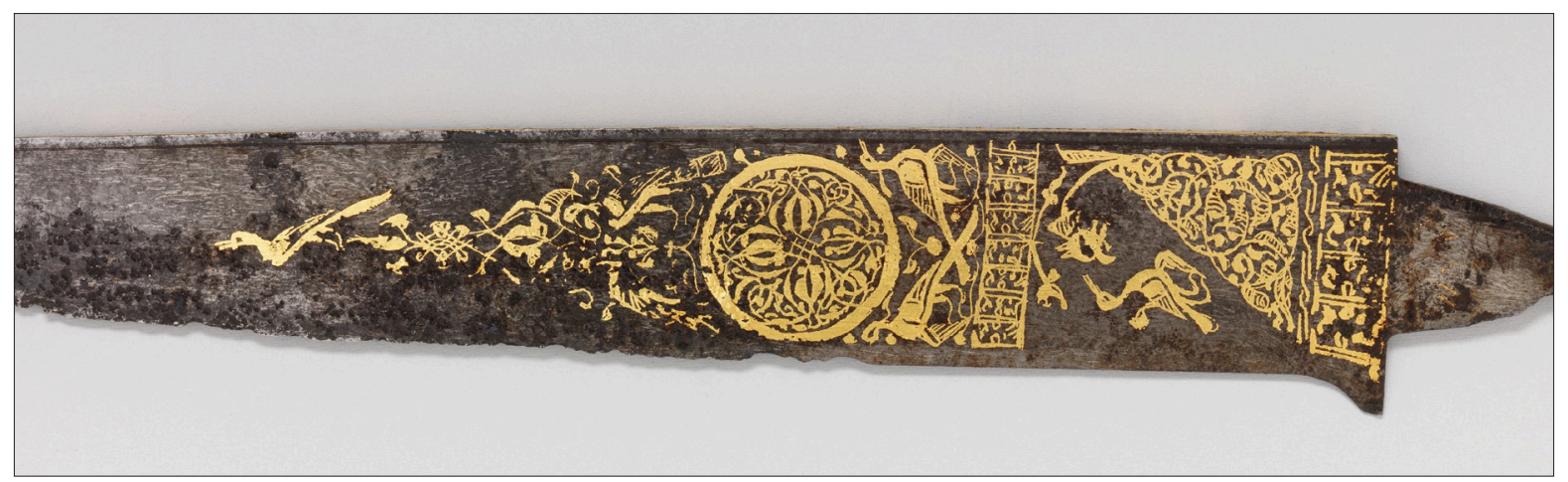

FIGURE 6. KNIFE BLADE (DETAIL), POSSIBLY AFGHANISTAN, CA. $11^{\text {TH }}-13^{\text {TH }}$ CENTURY. STEEL AND GOLD. METROPOLITAN MUSEUM OF ART (NEW YORK, NY), PURCHASE, ARTHUR OCHS SUlZberger GIFT, ACC. Nº. 2005.382. Image: Public Domain (CCo).

Another, trickier morphological term which may be related is found in a late $8^{\text {th }}$ century work on glass coloring by Jābir b. Hayyān (d. ca. 815). He gives a recipe for a «green oyster shell resembling corundum,» calling for a number of standard inorganic ingredients as well as something called «sadrat al- 'äj» or «sandarūs al'ajj.» ${ }^{89} \mathrm{Ahmad}$ al-Hassan, in his translation and commentary of the work, noted that sandarūs is a tree resin but was unsure how to gloss the complete phrase. ${ }^{90}$ Literally meaning «ivory resin,» it suggests an interior substance; perhaps appropriately, walrus osteodentine's clumpy appearance resembles frequently traded aromatic resins like Frankincense.

That different ivories were not all the same is apparent not only from the foregoing discussion, of materials used for their own sake, but also in references to faked products. Bìrūnī speaks of a man from Khwarazm who found a «tooth» which he had fashioned into blade hilts and subsequently sold in Mecca as $k h u t \bar{u}{ }^{91}$ This was

88. See AlexAnder, David: Islamic Arms and Armor. 194-95, cat. $n^{\circ} 75$; these unfortunately originate from uncontrolled excavations, thereby posing difficulty with dating.

89. Al-HASSAN, Ahmad Y.: «An Eighth Century Arabic Treatise on the Colouring of Glass: Kitäb al-Durra al-Maknuña (The Book of the Hidden Pearl) of Jābir ibn Hayyān (c. 721-c. 815)», Arabic Sciences and Philosophy 19 (2009), 151-52.

90. Al-Hassan, Ahmad Y., Op. cit. 151, n. 115. This term should be distinguished from its inversion, 'äj alsandarūs, which could mean an ivory-colored resin.

91. BīrūNī, On Precious Stones, 180. A somewhat similar story appears in the lapidary of al-Tifāshì (d. 1253), Flowers of Thoughts on the Gems of Stones (Azhär al-afkär fi jawähir al-ahjär). A certain merchant, travelling in Turkish lands, claimed to have purchased a «snake skull» for 55 dinārs, turning it into three knives (sakäkin) which he subsequently sold to a ruler for 500 dinärs. This material, too, was attributed the quality of sweating near poison. See ABUL HudA, Samar Najm (ed. and trans.): Arab Roots of Gemology: Ahmad ibn Yusuf Al Tifaschi's Best Thoughts on the Best of Stones. Lanham, MD, and London, Scarecrow Press, 1998, 134 (for English) and 52 (for Arabic). 
simply a matter of «passing,» rather than adulteration, though we also hear of the latter. An early $\mathrm{I}_{4}^{\text {th }}$ century Chinese connoisseur, Ye Sen, commented that khutū emitted a certain scent when rubbed; if a sample was instead odorless, it was to be taken as counterfeit.92 (Incidentally, this odor has been noted by modern authors and, I would note, might recall the mysterious «resin» of Ibn Ḥayyān. ${ }^{93}$ ) Regardless of the smell itself, the existence of a procedure for identifying fakes suggests the presence of such pieces in the market.

Some ivories were also modified to have alternative properties. Cutler notes medieval instructions of flattening ivory to widen it, though he finds them unconvincing. ${ }^{94}$ Some travelers, such as André Thevet (d. 1590), also noted instances of bending ivory; in his case, it was to pass it off as alicorn horn (i.e. narwhal). ${ }^{95}$ These are paralleled by the possibility of imitating rhino with buffalo horn..$^{96}$ Together, they suggest that different ivory and skeletal materials could be appreciated on their own terms as distinctive products -enough to warrant attempts to adulterate certain materials into seemingly higher quality ones.

This identification and, as in Bīrūnī, quality grading was dependent on largely on visual assessment of color, shape, and other features. Any confusion between materials was possible in large part to the distances involved in transporting them. Something about the craft of ivory carving, perhaps for this same reason, is frequently enmeshed in an ill-defined intercultural orbit. Many objects or groups of objects remain difficult to place in terms of workshop location or cultural space: oliphants, the Salerno ivories, Charlemagne's elephant, the Gansu ivory. ${ }^{97}$ Curiously, however, such interstitial, stylistically ambiguous ivories are elephantine. Meanwhile, walrus is instead differentiated by a technical and aesthetic matter -the treatment of osteodentine- approached as either a flaw or desideratum. Where elephant-based ivory objects mark a space through the use of a certain style, the space of walrus' reception is instead conditioned simply by the qualities of the constituent material.

\section{CONCLUSION}

As a coda, the question might remain how khutū, walrus, and other ivories as understood in central and western Asia were related to the north Atlantic, except

92. Cited by LAUfER, Berthold. Ivory in China. 55-56. For a brief biography of the author, see Zhou Mi's Record of Clouds and Mist Passing Before One's Eyes: An Annotated Translation, ed. and trans. Ankeney Weitz, Leiden and Boston: Brill, 2002, 29-31.

93. LAUfER, Berthold: Op. cit. 358 .

94. Cutler, Anthony: «The Making of Justinian Diptychs», Byzantion 54 (1984), 81.

95. Cited by Ettinghausen, Richard, Op. cit. 120-21.

96. Chapman, Jan: The Art of Rhinoceros Horn Carving in China. London, Christie's, 1999, 55-62.

97. On oliphants, see Shalem, Avinoam, Op. cit. 50-79; on the Salerno ivories, essays in DelL'ACQUA, Francesca et al. (eds.): The Salerno Ivories: Objects, Histories, Contexts. Berlin, Mann Verlag, 2016; on the so-called chessman, FLOOD, Finbarr Barry: «Conflict and Cosmopolitanism in 'Arab' Sind», in BROWN, Rebecca M. and HuTton, Deborah S. (eds.): A Companion to Asian Art and Architecture. Malden, MA and Oxford, Blackwell, 2011, 377-82; on the Gansu ivory, Rowan, Diana, Op. cit; ; on the problem of ivory identification in medieval Europe, RaNDALL, Richard H., Jr. The Golden Age of Ivory: Gothic Carvings in North American Collections. New York, Hudson Hills Press, 1993, 10-16. 
by coincidence of the animal's circumpolar distribution. Although medieval travellers speak about khutū and fish teeth coming from the land of the Turks, and sometimes more specifically Khwarazm, it should be kept in mind how this region was linked yet further north or northwest. $9^{8}$

Material exchanges between the Middle East and Scandinavia are attested primarily through a number of Norse coin hoards. Together, these amount to some 85,000 pieces, most often Abbasid gold dinärs and Samanid silver dirhams. ${ }^{99}$ Other objects are also known to have transited, such as an Iranian bronze brazier found in a Swedish forest, or a silver ring from a $9^{\text {th }}$ century grave, set with a glass cabochon featuring a Kufic inscription. ${ }^{100}$ There is even a Buddha sculpture from the Swat Valley, in today's Pakistan, which arrived in Sweden by the year $800 .{ }^{\text {Ior }}$ On the basis of numismatic epigraphy, it seems that the Volga trade -linking the Baltic and Caspian Seas- ended by the $\mathrm{II}^{\text {th }}$ century. Except for a period of political instability ca. II5O-I225, alternative routes were also in operation; following the Mongol invasions in the early ${ }_{1} 3^{\text {th }}$ century, these shifted west, toward the Black Sea. ${ }^{\text {IO2 }}$

Meanwhile, continental works were known to circulate in Iceland, though the exact mechanisms of exchange are often obscure. For example, a series of carved fir panels originating in the Skagafjörður district, later reused as rafters, were shown by Selma Jónsdóttir to reflect a Byzantine-style composition of the Last Judgment. She argued that a series of rogue bishops, familiar with the church of Monte Cassino in Italy, must have provided the compositional model for the work, produced around the year 1070. ${ }^{103}$ This would be, we might add by way of coincidence, about four years after the donation of a pair of bronze doors to Monte Cassino by a certain merchant named Maurus of Amalff. ${ }^{104}$ This same Maurus, patron

98. This is not to preclude a relationship between Iran and Central Asia with Siberia as well. In HOLLOWELL, Julie, Op. cit. 252, it is taken for granted that walrus ivory from the Bering Strait reached the Islamic world. The above reference to fish teeth from Korea (n. 82) may provide the link between these two regions.

99. JANSSON, Ingmar: «The Way to the East», in ROESDAHL, Else and WILSON, David M. (eds.): From Viking to Crusader: The Scandinavians and Europe, 800-1200. New York, Rizzoli, 1992, 80.

100. ÅDAHL, Karin: «An Early Islamic Incense Burner of Bronze in a Swedish Collection», in GNOLI, Gherardo and Panaino, Antonio. Proceedings of the First European Conference on Iranian Studies. Rome, Istituto Italiano per il Medio ed Estremo Oriente, 1991, 333-45; Ẅ̈rMLÄNDER, Sebastian K. T. S. et al.: «Analysis and interpretation of a unique Arabic finger ring from the Viking Age town of Birka, Sweden», Scanning: The Journal of Scanning Microscopies 37, 2 (2015), 131-37. For a discussion of objects found along the Volga route, see MichaILIDIS, Melanie, Op. cit. 323-29.

101. RamíRez-Weaver, Eric: «Islamic Silver for Carolingian Reforms and the Buddha-Image of Helgö: Rethinking Carolingian Connections with the East, 790-820», in WONG, Dorothy C. and HELDT, Gustav (eds.): China and Beyond in the Mediaeval Period: Cultural Crossings and Inter-Regional Connections. New Delhi, Manohar; Amherst, NY, Cambria Press, 2014, 171-86.

102. MARTIn, Janet: Treasure of the Land of Darkness: The Fur Trade and its Significance for Medieval Russia. Cambridge, Cambridge University Press, 1986, 16-34.

103. JónSDótTIR, Selma: An 11th Century Byzantine Last Judgement in Iceland. Reykjavík, Almenna Bókafélagið, 1959. Her discussion was not mentioned amongst the bibliography in the catalog entry for two other panels originating at the same farm in Flatatunga by Graham-CAmpBelL, James: Viking Artefacts: A Select Catalogue. London, British Museum, 1980, 161, cat. $n^{\circ} .539$.

104. Although he was apparently the original donor, most of the current panels appear to be later; see BLOCH, Herbert: «Origin and Fate of the Bronze Doors of Abbot Desiderius of Monte Cassino», Dumbarton Oaks Papers 41 (1987), 89-102. 
of the well-known Farfa Casket, may have been involved -somewhat ironically- in the African ivory trade. ${ }^{105}$

This last anecdote suggests the scale and seeming intractability of medieval «globalism.» None of the foregoing discussion is therefore decisive; rather, it simply suggests some alternative approaches to questions which have remained unresolved. Although I might disqualify myself as an interloper in questions of the Atlantic, Else Roesdahl has already noted that the «inter-relation between the demand for elephant and walrus ivory [...] is crucial to an understanding of the history of the Norse in Greenland.» ${ }^{106}$ In this, the Mediterranean and Central Asian market for walrus ivory should also be kept in mind. Inversely, specialists of «Islamic» art may find northwestern Europe remote to their own research. Yet the transit of ivory as raw material, if less often as complete artifacts, spanned most every circuit of trade which composed the trans-local medieval economy. ${ }^{\mathrm{I07}}$ It brings to mind Laufer's comment, used as the epigraph to this essay, about the circumpolar Thule entering «the general frame of history.» We are left to believe that seemingly distant points may yet turn out to be interrelated, if delicately.

105. GUÉRIN, Sarah M.: «Forgotten Routes?...» 87-91. On the casket's dating, see CRIVELLO, Fabrizio: «Gli avori del gruppo di 'Amalfi/Salerno'. Considerazioni sui presupposti, sulla cronologia e la localizzazione», in DELL'ACQUA, Francesca et al:: The Salerno Ivories: Objects, Histories, Contexts (Berlin, Gebr. Mann Verlag, 2017), 63-66.

106. RoESDAHL, Else: Op. cit. 189

107. ABU-LUGHOD, Janet, Op. cit.. 32-38. Indeed, the Norse/North Atlantic would constitute another, overlooked circuit in her schema -though also, looking at Atlantic scholarship, one in decline during her period of study. 


\section{BIBLIOGRAPHY}

\section{Primary Sources}

Abul Huda, Samar Najm (ed. and trans.): Arab Roots of Gemology: Ahmad ibn Yusuf Al Tifaschi's Best Thoughts on the Best of Stones. Lanham, MD, and London, Scarecrow Press, 1998.

Bīrūnī, Muḥammad ibn Aḥmad: The Book Most Comprehensive in Knowledge on Precious Stones. Trans. H. M. Said. Islamabad: Pakistan Hijra Council, I4Io/1989.

BīrūNī, Muḥammad ibn Aḥmad: Al-Jamāhir fī al-jawāhir. Ed. Yus̄uf al-Hādī. Iran: Sharikat al-Nashr al-'Ilmī wa'l-Thaqāfī, I995.

BOOK OF GIFTS AND RARITIES (Kitāb al-Hadāyā wa al-Tuḥaf). Ed. and trans. Ghāda al-Hiijjāwī al-Qaddūmī. Cambridge, MA: Harvard Center for Middle Eastern Studies, I996.

CAO, Zhao: Chinese Connoisseurship: The Ko Ku Yao Lun, The Essential Criteria of Antiquities. Ed. and trans. Sir Percival David. New York: Praeger, I97I.

Cosmas Indicopleustès: Topographie chrétienne, Tome IIl. WolsKa-Conus, Wanda (trans.): Paris, Les Éditions du Cerf, 1973.

IBN FAḌLĀN, Aḥmad: «Mission to the Volga.» Trans. James E. Montgomery. In Two Arabic Travel Books, New York: New York University Press, 2014.

GARDīzī, 'Abd al-Ḥayy ibn Zaḥhāk: The Ornament of Histories: A History of the Eastern Islamic Lands, AD 650-104I. Ed. and trans. Edmund Bosworth . London: I. B. Tauris, 2011.

Al-Hassan, Ahmad Y.: «An Eighth Century Arabic Treatise on the Colouring of Glass: Kitāb al-Durra al-Maknūna (The Book of the Hidden Pearl) of Jābir ibn Ḥayyān (c. 72I-c. 815).» Arabic Sciences and Philosophy I9 (2009), I2I-56.

Lund, Niels (ed.) and Fell, Christine E. (trans.): Two Voyagers at the Court of King Alfred. York, William Sessions Limited, 1984.

Minorsky, Vladimir (ed. and trans.): Sharaf al-Zamān Ṭähir Marvazì on China, the Turks, and India. London: Royal Asiatic Society, 1942.

Pliny THE Elder: Natural History, Volume III: Books 8-II. Trans. Harris Rackham. Cambridge, MA: Harvard University Press, I940.

Sīrāpì, Abū Zayd Ḥasan ibn Yazīd: «Accounts of China and India.» Trans. Tim MackintoshSmith. In Two Arabic Travel Books, New York: New York University Press, 2014.

Zhou, Mi: Zhou Mi's Record of Clouds and Mist Passing Before One's Eyes: An Annotated Translation. Ed. and trans. Ankeney Weitz. Leiden and Boston: Brill, 2002.

\section{Secondary Literature}

ABu-Lughod, Janet: Before European Hegemony: The World System, A.D. I250-I350. New York: Oxford University Press, I989.

ÅDAHL, Karin: «An Early Islamic Incense Burner of Bronze in a Swedish Collection», in Gnoli, Gherardo and Panaino, Antonio (eds.): Proceedings of the First European Conference on Iranian Studies. Rome, Istituto Italiano per il Medio ed Estremo Oriente, I99I, 333-45.

ALEXANDER, David G.: The Arts of War: Arms and Armour of the $7^{\text {th }}$ to $19^{\text {th }}$ Centuries. London: Nour Foundation, 1992.

AleXANDeR, David G: Islamic Arms and Armor in the Metropolitan Museum of Art. New York: Metropolitan Museum of Art; New Haven: Yale University Press, 2015. 
ArNeborg, Jette: «The High Arctic 'Utmark' of the Norse Greenlanders.» In ANDERsson, Hans, ERSGÅRD, Lars, and Svensson, Eva (eds.): Outland Use in Preindustrial Europe. Lund, Lund University Institute of Archaeology, 1998, 156-66.

ARNEBORG, Jette: «Norse Greenland - research into abandonment.» In KristianSEN, Svart, Roesdahl, Else, and Graham-CAmpbell, James (eds.): Medieval Archaeology in Scandinavia and Beyond: History, trends and tomorrow. Aarhus, Aarhus University Press, 2015, 257-7I.

ARUZ, Joan: «Art and Networks of Interaction across the Mediterranean.» In ARUZ, Joan, GrafF, Sarah B., and RAKIC, Yelena (eds.): Assyria to Iberia at the Dawn of the Classical Age. New York, Metropolitan Museum of Art, 2014, II2-24.

BANERJEE, Arun: «Non-Destructive Investigation of Ivory by FTIR and Raman Spectroscopy.» In BüHL, Gudrun, Cutler, Anthony, and EfFenberger, Arne (eds.): Spätantike und byzantinische Elfenbeinbildwerke im Diskurs. Wiesbaden, Reichert Verlag, 2008, I-7.

Berglund, Joel: «The Decline of the Norse Settlements in Greenland», Arctic Anthropology 23, nos. I-2 (I986), I09-35.

Bloch, Herbert: «Origin and Fate of the Bronze Doors of Abbot Desiderius of Monte Cassino.» Dumbarton Oaks Papers 4I (1987), 89-I02.

BošKović, Dora: Zbinka Jatagana u Hrvatskom Povijesnom Muzeju u Zagrebu. Zagreb: Hrvatski Povijesni Muzej, 2006.

BuRACK, Benjamin: Ivory and its Uses. Rutland, VT and Tokyo: Charles E. Tuttle, I984.

Burragato, F. et al:: «New Forensic Tool for the Identification of Elephant or Mammoth Ivory», Forensic Science International 96 (1998), I89-96.

Cammann, Schuyler V. R.: "Carvings in Walrus Ivory», University Museum Bulletin 18, 3 (I954), 2-3I.

CAsid, Jill H. and D'souzA, Aruna (eds.): Art History in the Wake of the Global Turn. Williamstown, Clark Art Institute, 2014.

Chapman, Jan: The Art of Rhinoceros Horn Carving in China. London, Christie's, 1999.

Choкsy, Jamsheed K.: «Sassanians.» In Bowersock, G. W., Brown, Peter, and Grabar, Oleg (eds.): Late Antiquity: Guide to the Postclassical World, Cambridge, MA Belknap Press, I999.

CRIvello, Fabrizio: «Gli avori del gruppo di 'Amalfi/Salerno'. Considerazioni sui presupposti, sulla cronologia e la localizzazione», in DelL'ACQUA, Francesca et al.: The Salerno Ivories: Objects, Histories, Contexts, Berlin, Gebr. Mann Verlag, 2017, 6I-72.

CUTLER, Anthony: «The Making of Justinian Diptychs», Byzantion 54 (I984), 75-II5.

CutLer, Anthony: The Craft of Ivory: Sources, Techniques, and Uses in the Mediterranean World, A.C. 200-I400. Washington, DC, Dumbarton Oaks, 1985.

DANKoff, Robert: «A Note on khutū and chatuq», Journal of the American Oriental Society 93, 4 (1973), 542-43.

DAvies, Glyn and GuÉRIN, Sarah: «Introduction», The Sculpture Journal 23, I (20I4), 7-I2.

Dell'ACQua, Francesca et al. (eds.): The Salerno Ivories: Objects, Histories, Contexts. Berlin, Mann Verlag, 2016.

Delliaux, Maxime: «Le morse et le phoque dans les mers du nord au Moyen Âge: Chasse, exploitation, commerce. Une approche par les textes», Anthropozoologica 5I, 2 (2016), $85-96$.

Duggan, T. M. P.: «Diplomatic Shock and Awe: Moving, Sometimes Speaking, Islamic Sculptures», Al-Masaq: Islam and the Medieval Mediterranean 2I, 3 (2009), pp. 229-67.

Dugmore, Andrew J. et al.: "Cultural adaptation, compounding vulnerabilities and conjunctures in Norse Greenland», Proceedings of the National Academy of Sciences 109, Io (2012), 3658-63. 
Edwards, H. G. M., Nik Hassan, N. F. and Arya, N.: «Evaluation of Raman Spectroscopy and Application of Chemometric Methods for the Differentiation of Contemporary Ivory Specimens I: Elephant and Mammalian Species», Journal of Raman Spectroscopy 37, I-3 (2006), 353-60.

ENGHOFF, Inge Bødker: Hunting, fishing and animal husbandry at The Farm Beneath the Sand, Western Greenland: An archaeozoological analysis of a Norse farm in the Western settlement. Copenhagen, Danish Polar Center, 2003.

EspinOzA, Edgard O. and MANN, Mary-Jacque: Identification Guide for Ivory and Ivory Substitutes. Washington, DC, World Wildlife Fund, 1992.

FlooD, Finbarr Barry: «Conflict and Cosmopolitanism in 'Arab' Sind.» In BROwN, Rebecca M and Hutton, Deborah S. A.: A Companion to Asian Art and Architecture, Malden, MA and Oxford, Blackwell, 2011, 365-97.

Fitzhugh, William W, Crowell, Aron L, and Hollowell, Julie (eds.): Gifts from the Ancestors: Ancient Ivories of Bering Strait. New Haven and London, Yale University Press, 2009.

Forte, Angelo, Oram, Richard and Pedersen, Frederik: Viking Empires. Cambridge, Cambridge University Press, 2005.

FREI, K. M. et al: «Was it for Walrus? Viking Age settlement and medieval walrus ivory trade in Iceland and Greenland», World Archaeology 47, 3 (2015), 439-66.

FREI, Richard N: «Byzantine and Sasanian Trade Relations with Northeastern Russia», Dumbarton Oaks Papers 26 (1972), 263-69.

Gaborit-Chopin, Danielle: «Le commerce de l'ivoire en Méditerranée durant le Moyen Âge», Bulletin Archéologique 34 (2008), 23-33.

Gerritsen, Anne and Riello, Giorgio: «Spaces of Global Interactions: The Material Landscapes of Global History», In eadem (eds.): Writing Material Culture History (London, Bloomsbury, 20I5), III-33.

GilL, D. W. J.: «The Ivory Trade», in FitTon, J. Lesley: Ivory in Greece and the Eastern Mediterranean from the Bronze Age to the Hellenistic Period. London, British Museum, I992, 233-37.

Gosden, Chris: «Making Sense: Archaeology and Aesthetics», World Archaeology 33, 2 (200I), I63-67.

Graham-CAMpbell, James: Viking Artefacts: A Select Catalogue. London: British Museum, I980.

GUÉRIN, Sarah M.: «Avorio d'ogni regione: The Supply of Elephant lvory to Northern Europe in the Gothic Era», Journal of Medieval History 36 (2010), 156-74.

GUÉRIN, Sarah M.: «Forgotten Routes? Italy, Ifriq̄iya and the Trans-Saharan Ivory Trade», Al-Masaq: Islam and the Medieval Mediterranean 25, I (2013), 70-9I.

GuY, John: «Rare and Strange Goods: International Trade in Ninth-Century Asia», In KRAHL, Regina et al. (eds.): Shipwrecked: Tang Treasures and Monsoon Winds. Washington, DC, Arthur M. Sackler Gallery, 20I0, I8-27.

Hall, M. A.: «An Ivory Knife Handle from the High Street, Perth, Scotland: Consuming Ritual in a Medieval Burgh», Medieval Archaeology 45 (200I), I69-88.

Harrison, Ramona, RoberTs, Howell M, and AdDERLEv, W Paul: «Gásir in Eyjafjörđur: International Exchange and Local Economy in Medieval Iceland», Journal of the North Atlantic I (2008), 99-II9.

Hoffman, Eva R.: «Pathways of Portability: Islamic and Christian Interchange from the Tenth to the Twelfth Century», Art History 24, I (200I), I7-50.

JónSDótTiR, Selma: An II ${ }^{\text {th }}$ Century Byzantine Last Judgement in Iceland. Reykjavík, Almenna Bókafélagið, I959. 
KelleR, Christian: «Furs, Fish, and lvory: Medieval Norsemen at the Arctic Fringe», Journal of the North Atlantic 3 (2010), I-23.

KingDon, Jonathan (ed.): Mammals of Africa. London, Bloomsbury, 2013.

KIPARSKY, Valentin: L'Histoire du morse. Helsinki: Suomalainen Tiedeakatemia, I952.

KunZ, George Frederick: Ivory and the Elephant in Art, in Archaeology, and in Science. Garden City, NY, Doubleday, Page, and Company, igi6.

LAUfER, Berthold: «Arabic and Chinese Trade in Walrus and Narwhal lvory», Toung Pao I4, 3 (1913), 315-70.

LAUfER, Berthold: Ivory in China. Chicago, Field Museum of Natural History, I925.

LAVERS, C. and KNAPP, M.: «On the origin of khutū», Archives of Natural History 35, 2 (2008), 306-I8.

Levine, Adam Harris: «Putting Together the Pieces: Composite Techniques in Gothic Ivories», Sculpture Journal 23, I (2014), 4I-50.

Lin, James C. S.: The Immortal Stone: Chinese Jades from the Neolithic Period to the Twentieth Century. London, Scala, 2009.

LOCKE, Michael: «The Structure of Ivory», Journal of Morphology 269 (2008), 423-50.

Long, D. A., Edwards, H. G. M., and Farwell, D. W.: «The Goodmanham Plane: Raman Spectroscopic Analysis of a Roman Ivory Artefact», Journal of Raman Spectroscopy 39, 3 (2008), 322-30.

LyNNERUP, Niels: «Endperiod Demographics of the Greenland Norse», Journal of the North Atlantic 7 (2014), I8-24.

MACGREGOR, Arthur: Bone, Antler, Ivory \& Horn: The Technology of Skeletal Materials since the Roman Period. London, Croom Helm and Totowa, NJ, Barnes \& Noble, I985.

Mankiw, N. Gregory: Principles of Economics, Fourth Edition. Mason, OH, Thomson SouthWestern, 2007.

MANn, William R. and MARTs, Charles M.: Ivory Identification: A Photographic Reference Guide. Temple Hills, MD, Ivorymann Publishing, 2013.

Manutchehr-Danal, Mohsen: Dictionary of Gems and Gemology. New York, Springer, 2005.

MARTIN, Janet: Treasure of the Land of Darkness: The Fur Trade and its Significance for Medieval Russia. Cambridge, Cambridge University Press, I986, I6-34.

Michallidis, Melanie: «Samanid Silver and Trade along the Fur Route», Medieval Encounters I8 (2012), 3I5-38.

MoHAmed, Bashir: The Arts of the Muslim Knight: The Furusiyya Art Foundation Collection. Milan, Skira, 2008.

NøRLund, Poul: Viking Settlers in Greenland. Cambridge, Cambridge University Press, 1936.

NyвоRG, Ebbe: «The Beginnings of Gothic Ivory Sculpture: Recent Discoveries in a Group of Danish Ivories», The Sculpture Journal 23, I (2014), 3I-39.

Ogilvie, Astrid E. J. : «Seals and Sea Ice in Medieval Greenland», Journal of the North Atlantic 2 (2009), 60-80.

Peск, Amelia (ed.): Interwoven Globe: The Worldwide Textile Trade, I500-I80o. New York, Metropolitan Museum of Art, 2013.

Penniman, T. K.: Pictures of Ivory and other Animal Teeth, Bone and Antler. Oxford: Oxford University Press for the Pitt Rivers Museum, I952.

PIerCE, Elizabeth: «Walrus Hunting and the Ivory Trade in the North Atlantic.» In CALDWELL, David H. and Hall, Mark A. (eds.): The Lewis Chessmen: New Perspectives. Edinburgh, National Museums Scotland, 2014, I68-83.

PINDER-Wilson, Ralph: «'Ā $\bar{d} j$.» Encyclopedia of Islam, online. 
Ramírez-Weaver, Eric: «Islamic Silver for Carolingian Reforms and the Buddha-Image of Helgö: Rethinking Carolingian Connections with the East, 790-820.» In WoNG, Dorothy C. and Held , Gustav (eds.): China and Beyond in the Mediaeval Period: Cultural Crossings and Inter-Regional Connections. New Delhi, Manohar; Amherst, NY, Cambria Press, 20I4, I7I-86.

Randall, Richard H. Jr.: The Golden Age of Ivory: Gothic Carvings in North American Collections. New York, Hudson Hills Press, I993.

RichaRdSON, Catherine: «Written Texts and the Performance of Materiality.» In GerRitsen Anne and RiEllo Giorgio (eds.): Writing Material Culture History, (London: Bloomsbury, 2015), 43-58.

Roesdahl, Else: «L'ivoire de morse et les colonies norroises», Proxima Thulé3 (I998), Io-48.

RoESDAHL, Else: «Walrus ivory - demand, supply, workshops, and Greenland.» In Viking and Norse in the North Atlantic: Selected Papers from the Proceedings of the Fourteenth Viking Congress (Tórshavn: Føroya Fróðskaparfelag, 2005), 182-91.

Roesdahl, Else and Wilson, David M. (eds.): From Viking to Crusader: The Scandinavians and Europe, 800-I200. New York, Rizzoli, 1992.

Rouse, Robert: «Dynamic fluidity and wet ontology: Current work on the archipelagic North Sea», postmedieval 7, 4 (2016), 572-80.

Rowan, Diana P.: «Reconsideration of an Unusual Ivory Diptych», Artibus Asiae 46, 4 (1985), $25 \mathrm{I}-304$.

Schafer, Edward H.: The Golden Peaches of Samarkand: A Study of T'ang Exotics. Berkeley and Los Angeles, University of California Press, 1963.

Seaver, Kirsten A.: «Desirable Teeth: The Medieval Trade in Arctic and African Ivory», Journal of Global History 4, 2 (2009), 27I-92.

Shalem, Avinoam: The Oliphant: Islamic Objects in Historical Context. Leiden and Boston, Brill, 2004.

Sharifian, Farzad: «Cultural Linguistics and Linguistic Relativity», Language Sciences 59 (2017), 83-92.

SeARS, Elizabeth: «lvory and Ivory Workers in Medieval Paris.» In BARNET, Peter (ed.): Images in Ivory: Precious Objects of the Gothic Age. Detroit, Detroit Institute of Arts; Princeton: Princeton University Press, I997, I8-37.

Shimoyama, Masahiko, Morimoto Susumu, and Ozakı, Yukihiro: «Non-destructive analysis of the two subspecies of African elephants, mammoth, hippopotamus, and sperm whale ivories by visible and short-wave near infrared spectroscopy and chemometrics», Analyst I29 (2004), 559-63.

SINGH, Rina Rani et al.: «Using Morphometric and Analytic Techniques to Characterize Elephant lvory», Forensic Science International I62 (2006), I44-5I.

TAKeUCHI, T., NAKANO, Y., and Kolke, H.: «Neutron Activation Analysis of lvory of African Elephants,» Journal of Radioanalytical and Nuclear Chemistry 205, 2 (I996), 30I-309.

PÓRARINSSON, Guðmundur G: «The Lewis Chessmen: The Icelandic Theory.» In CALDwELL, David H. and Hall, Mark A. (eds.): The Lewis Chessmen: New Perspectives. Edinburgh, National Museums Scotland, 20I4, 20I-I8.

Van Der Merwe, N. J. et al.: «Source-Area Identification of Elephant Ivory by Isotopic Analysis», Nature 346 (1990), 744-746.

WÄRMLÄNDER, Sebastian K. T. S. et al.: «Analysis and interpretation of a unique Arabic finger ring from the Viking Age town of Birka, Sweden», Scanning: The Journal of Scanning Microscopies 37, 2 (2015), I3I-37. 
Wart, J. C. Y.: «Chinese Connoisseurship: The Ko Ku Yao Lun. The Essential Criteria of Antiquities by Percival David», Journal of the Hong Kong Branch of the Royal Asiatic Society I2 (I972), 2I3-I8.

Welch, Stuart Cary: India: Art and Culture, I300-I900. New York, Metropolitan Museum of Art, I985.

Williamson, Paul: Medieval Ivory Carvings: Early Christian to Romanesque. London, V\&A Publishing, 2010.

Williamson, Paul and Davies, Glyn: Medieval Ivory Carvings: I200-I550. 2vv. London, V\&A Publishing, 20I4.

Wu, Jie: «A Study of Group Compositions in Early Tang China (618-713)», Unpubl. Ph.D. diss.: University of Washington, 2008.

YıN, Zuowei et al.: «A Comparison of Modern and Fossil Ivories Using Multiple Techniques», Gems \& Gemology 49, I (2013), I6-27. 
AÑO 2017

NUEVA ÉPOCA

ISSN: $1130-4715$

E-ISSN 2340-1478

Dossier by Avinoam Shalem: Treasures of the Sea: Art before Craft? - Tesoros del mar: ¿El Arte antes de la destreza? por Avinoam Shalem

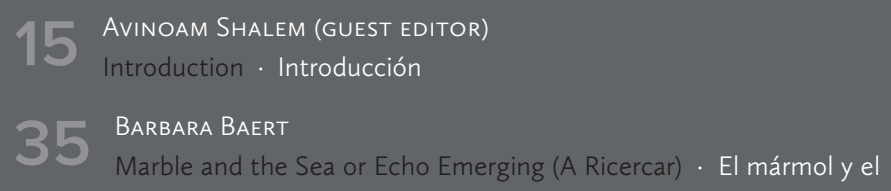
mar o el surgimiento del eco (una búsqueda)

55 KAREN PINTO

Vision. A través de los ojos de Dios: la sacralidad de los mares en la visión cartográfica islámica

8) MatTHEW ElLiott Gillman

- A Tale of Two Ivories: Elephant and Walrus . Una historia de dos marfiles: el elefante y la morsa

107 PERsis BERLEKAMP

Reflections on a Bridge and its Waters: Fleeting Access at Jazirat b.

'Umar / Cizre / 'Ain Diwar / (Im)mobile displacements · Reflejos sobre un puente y sus aguas: un acceso rápido a Jacirat b. 'Umar / Cizre / 'Ain Diwar

\subsection{HANNAH BAADER}

Livorno, lapislázuli, geología y los tesoros del mar en 1604

\section{Miscelánea · Miscellany}

174 JOAN DURAN-PORTA

Nuevos datos sobre la temprana difusión del ajedrez en los Pirineos, y una reflexión sobre las piezas de Àger . New Evidences on the Early Spread of Chess in the Pyrenees, and a Consideration about the Àger Set

189 BEgoña Alonso Ruiz de Torrelaguna (Madrid) en el contexto de la construcción de bóvedas baídas en el siglo XVI . The Chapel of the Annunciation in the Church of Santa María Magdalena in Torrelaguna (Madrid) in the Context of the Construction of Pendentives Vaults in the $16^{\text {th }}$ Century

213 Esteban Ángel Cotillo Torrejón

capilla de San Isidro en Madrid. Marian Cycle of Francisco Caro and Andrés de Leito for the Royal Chapel of San Isidro in Madrid
24.7 David ChILlón Raposo siglo XVII: el origen de la devoción a Santa Rosalía . Sicilian Aesthetic Sensibility in the City Seville at the End of the $17^{\text {th }}$ Century: Introduction of the Devotion to Santa Rosalía

273 David SERRANo León

Algunos casos aislados. Euan Uglow y Antonio López . The Relationship between Time and Methodology in Naturalist Painting. Some Isolated Cases. Euan Uglow and Antonio López

$289 M^{a}$ DEL PILAR GARRIDO REDONDO

Isabel Quintanilla: The Realism of the Daily Life. Hyperrealism?

345 Guillermo Aguirre-Martínez

La casa como puerta de entrada hacia un orden arquetípico en la obra plástica de Thomas Virnich. The House as an Entrance Door into an Archetypal Order in Thomas Virnich's Sculptural Work

333 LUCAS E. LORDUY OSÉS

Mexican Women Photographers: Images of Dissidence and Empowerment

353 Estefanía López Salas

escuela · Durán Salgado, de la Sota, Samos: Two Projects for a Farm School

391 Daniel López Bragado \& Víctor-Antonio Lafuente SÁnchez

Parador Nacional de Turismo de Zamora. The Palace of the Counts of Alba de Aliste and their Transformation into Parador Nacional de Turismo of Zamora

4.17 PATRICIA García-Montón GonzÁlez

losé Gabriel Navarro y el Museo del Prado. He Came with a Lot of Projects and Materials. The Ecuadorian Diplomat José Gabriel Navarro and the Prado Museum

4.51 Pablo Allepuz García

The Historiographic and/or Archeological Impulse in Spain. Genesis, Reception, Possibilities

1.72 Verónica CAPASSO

43 Sobre la construcción social del espacio: contribuciones para los estudios sociales del arte - About social Construction of Space: Contributions for Social Studies of Art 
AÑO 2017

NUEVA ÉPOCA

ISSN: 1130-4715

E-ISSN 2340-1478

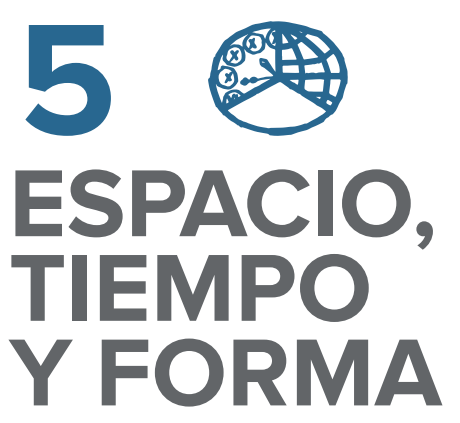

Reseñas • Book Review

4.93 Amparo Serrano de Haro: Algunos libros recientes de arte y género BARroso VILLAR, Julia, Mujeres árabes en las artes visuales, Zaragoza, Prensas de la Universidad de Zaragoza, 2016.

MÉNDEZ BAIGES, Maite (ed.), Arte Escrita: texto, imagen y género en el arte contemporáneo, Granada, Comaresarte, 2017

\subsection{José Antonio Vigara Zafra}

Àngel, Francisco Isidro; COMPANY, Ximo; GARRIDO, Carmen; HerRERo, Migu

\subsection{Borja Franco Llopis}

IRIGOYEn-García, Javier: Moors Dressed as Moors. Clothing, Social Distinction, and Ethnicity in Early Modern Iberia. Toronto, University of Toronto Press, 2017

\section{1 antonio Perla de las Parras}

LAGUNA PAúl, Teresa (coord.): Facistol de la catedral de Sevilla. Estudiosy recuperación, Sevilla, Editorial Universidad de Sevilla, Cabildo de la S.M.P.I. Catedral de Sevilla, 2016 